\title{
Air quality in the megacity of São Paulo: evolution over the last 30 years and future perspectives
}

Maria de Fatima Andrade ${ }^{1}$, Prashant Kumar $^{2,3}$ Edmilson Dias de Freitas $^{1}$, Rita Yuri Ynoue ${ }^{1}$, Jorge Martins ${ }^{4}$, Leila D. Martins ${ }^{4}$, Thiago Nogueira ${ }^{1}$, Pedro Perez-

Martinez $^{1}$, Regina Maura de Miranda ${ }^{5}$,Taciana Albuquerque ${ }^{6}$, Fabio Luiz Teixeira Gonçalves ${ }^{1}$, Beatriz Oyama ${ }^{1}$ and Yang Zhang $^{7}$

${ }^{1}$ Department of Atmospheric Sciences, Institute of Astronomy, Geophysics and Atmospheric Sciences, University of São Paulo, São Paulo, Brazil

${ }^{2}$ Department of Civil and Environmental Engineering, Faculty of Engineering and Physical Sciences (FEPS), University of Surrey, Guilford GU2 7XH, UK

${ }^{3}$ Environmental Flow (EnFlo) Research Centre, Faculty of Engineering and Physical Sciences, University of Surrey, Guildford GU2 7XH, UK

${ }^{4}$ Federal University of Technology, Parana, Av. Dos Pioneiros, 3131, Londrina, 86047125, Brazil

${ }^{5}$ EACH - School or Arts, Science and Humanities, University of São Paulo, São Paulo,

$$
\text { Brazil }
$$

${ }^{6}$ Federal University of Minas Gerais, Department of Sanitary and Environmental Engineering, School of Engineering, Belo Horizonte, Brazil

${ }^{7}$ Department of Marine, Earth, and Atmospheric Sciences, North Carolina State University, Raleigh, North Carolina, United States 


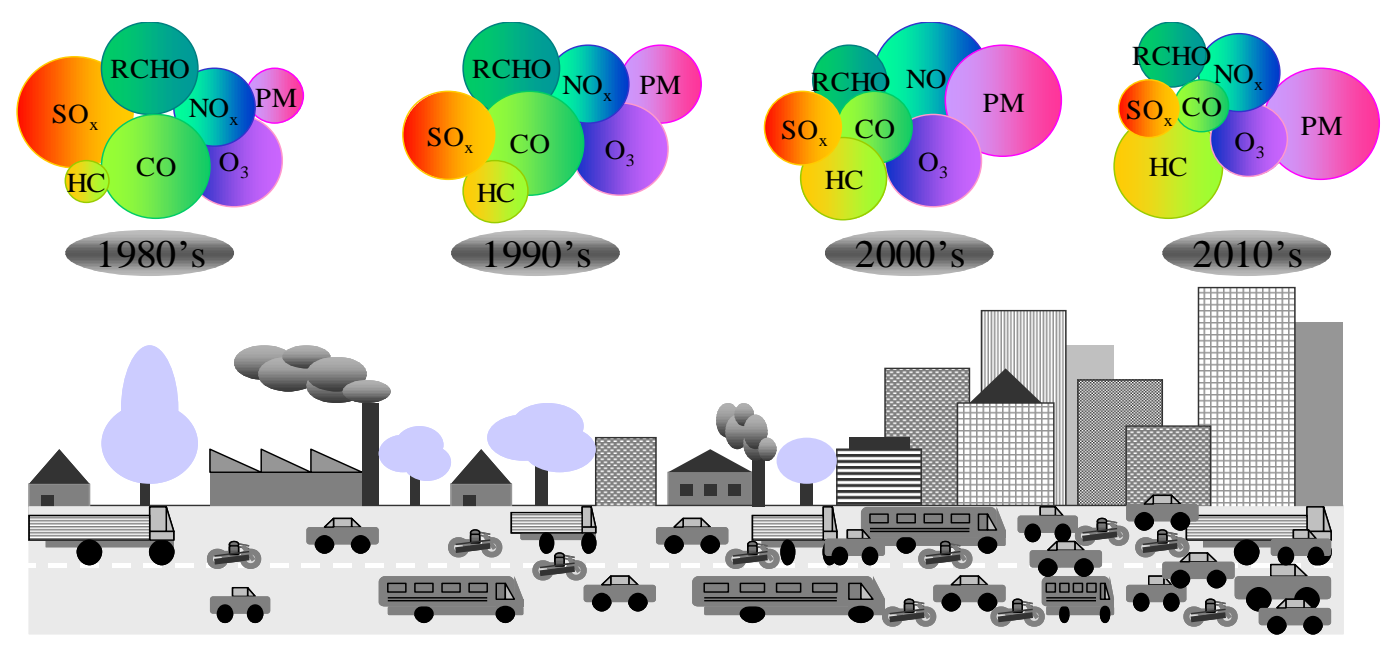

Abstract

We present a comprehensive review of published results from the last 30 years regarding the sources and atmospheric characteristics of particles and ozone in the Metropolitan Area of São Paulo (MASP). During the last 30 years, many efforts have been made to describe the emissions sources and to analyse the primary and secondary formation of pollutants under a process of increasing urbanisation in the metropolitan area. From the occurrence of frequent violations of air quality standards in the 1970s and 1980s (due to the uncontrolled air pollution sources) to a substantial decrease in the concentrations of the primary pollutants, many regulations have been imposed and enforced, although those concentrations do not yet conform to the World Health Organization guidelines. The greatest challenge currently faced by the São Paulo State Environmental Protection Agency and the local community is controlling secondary pollutants such as ozone and fine particles. Understanding the formation of these secondary pollutants, by experimental or modelling approaches, requires the description of the atmospheric chemical processes driven by biofuel, ethanol and biodiesel emissions. Exposure to air pollution is the cause of many injuries to human health, according to many studies performed not only in the region but also worldwide, and affects susceptible populations such as children and the elderly. The MASP is the biggest megacity in the Southern Hemisphere, and its specifics are important for other urban areas that are facing the challenge of intensive growth that puts pressure on natural resources and worsens the living conditions in urban areas. This text discusses how imposing regulations on air quality and emission sources, mainly related to the transportation sector, has affected the evolution of pollutant concentrations in the MASP. 
Keywords: Emissions; Fuel and energy; Air Pollution; Exposure; Climate Change; Megacity of São Paulo

\section{Research highlights}

$\Rightarrow \quad$ Evolution of air quality in the Metropolitan Area of São Paulo under emissions control

$\Rightarrow \quad$ The time evolution of the trace elements concentration in fine particles

$\Rightarrow \quad$ The impact of biofuels on air quality in the Metropolitan Area of São Paulo

$\Rightarrow \quad$ Formation of secondary organic and inorganic aerosol from biofuel emissions

$\Rightarrow \quad$ Ozone formation and oxygenated fuels

$\Rightarrow \quad$ Public health effects of air pollution, by age group

\section{Introduction}

The Metropolitan Area of São Paulo (MASP) is a megacity with a population of 21 million (UN, 2014; City Population, 2016; IBGE, 2016), corresponding to more than $11 \%$ of the total population of Brazil. It covers an area of $7,947 \mathrm{~km}^{2}$ and has a demographic density of 2,653.9 inhabitants $\mathrm{km}^{-2}$. The current share of people using underground transportation in the MASP is 4.2 million, compared with approximately 3.6 million passengers per day in London. The first studies of air quality in the MASP were conducted in the late 1970s, when the São Paulo State Companhia de Tecnologia de Saneamento Ambiental (CETESB, Environmental Protection Agency) was created. At that time, the state of São Paulo was undergoing considerable economic growth and migration from other states in Brazil (Marques, 2016). Disorganised urbanisation and an increase in the number of air pollution sources led to a critical situation concerning air quality. The concentrations of regulated pollutants regularly violate the air quality standards. In the 1980s, programs to control the emissions of sulfur dioxide $\left(\mathrm{SO}_{2}\right)$ by industries began with a change from residual oil-fired boilers to electrical boilers. As the transport sector became the main actor for pollutant emissions, the most effective program for the reduction of such emissions was the nationwide implementation of the Programa de Controle da Poluição do Ar por Veículos Automotores (PROCONVE, Program for the Control of Air Pollution Emissions by Motor Vehicles), which became the main driver for reducing air quality violations in Brazilian cities (Brazilian National Environmental Council Resolution no. 315/2002). According to Andrade et al. (2012), 
who applied receptor models to elemental concentrations of fine particles in six capital cities in Brazil (São Paulo, Rio de Janeiro, Curitiba, Belo Horizonte, Recife and Porto Alegre), vehicular emissions are the main source of fine particles in the largest cities of the country. From 2001 to 2012, the vehicle fleet in the MASP grew by 76\% (Caderno Metropole/Observatorio das Metropoles, 2013) and reached 11,858,293 in 2014 (DENATRAN, 2015; CETESB, 2014). Another important factor for the reduction of carbon monoxide $(\mathrm{CO})$ emissions by the fleet was the creation of the National Ethanol Program, known as "Proálcool", started in 1975 (to stimulate the use of ethanol as fuel), which mandated the use of a mixture of ethanol and gasoline (creating gasohol). That program had the side effect of increasing the area of sugarcane cultivation and biomass burning (from the agricultural procedure of burning off the leaves and sheaths, collectively known as bagasse, before harvesting). Currently, such burn-offs occur on only $10 \%$ of the land planted with sugarcane and are supposed to be totally banned by 2017.

Although the emission per vehicle has decreased with time, the concentrations of ozone and fine particles with a diameter less than or equal to $2.5 \mu \mathrm{m}\left(\mathrm{PM}_{2.5}\right)$ are not yet controlled (Salvo and Geiger, 2014; Perez-Martinez et al., 2015). There have been many efforts to understand the role of biofuels in the formation of secondary particles (inorganic and organic) and ozone (e.g. Nogueira et al., 2015a; Karjalainen et al., 2016). Oliveira et al. (2016) analysed the time variation of the particle number concentrations, ozone and fine particles, showing the impact of vehicle emissions on the formation of these secondary pollutants. A modelling approach is being considered in these studies of the secondary formation of ozone and particles. In a recently published work using a numerical model to investigate the impact of vehicular emissions on the formation of fine particles in the MASP, Vara-Vela et al. (2016) suggested that over $40 \%$ of the fine particle mass formation was due to the emission of hydrocarbons (HC), mainly aromatics. Concerning the role of biofuels in the formation of ozone in the MASP, there have been some relevant studies. Nogueira et al. (2014) observed an increase in the formaldehyde/acetaldehyde ratio. In a subsequent study (Nogueira et al., 2015b), the authors showed that, among the carbonyl species, formaldehyde and acetaldehyde are the two largest carbonyl contributors to ozone production. They also showed that these are the most abundant species, light duty vehicles (LDV) emitting up to 3.5 times more formaldehyde and acetaldehyde in the MASP than in California. In addition, Dominutti 
et al. (2016) found the concentrations of non-methane hydrocarbons to be higher in the MASP than in other megacities worldwide (Beijing, London, Los Angeles and Paris), despite the decreases in the concentrations of these species observed in recent years in the MASP.

In this review, we will show how the implementation of political regulations had a positive impact on air quality and source apportionment in the MASP, considering biomass burning from local sources, as well as from distant sources that can affect air quality in the MASP through long-range transport (hereafter referred to as external sources). New studies concerning the formation of secondary organic and inorganic aerosols are also presented within the scope of the specific volatile organic compound (VOC) emissions into the MASP atmosphere from the combustion of biofuels.

The evolution of pollutant concentrations in megacities in other parts in the world has been studied. For example, Parrish et al. (2011) showed that, despite considerable economic growth, Los Angeles, New York and Mexico City have made enormous progress in controlling the factors that led to impairment of the air quality. However, the authors also stated that air quality has to be improved in order to be in line with the recommendations of the World Health Organization (WHO).

European Air Quality Directive no. 2008/50/EC encouraged the use of models in combination with the monitoring of zones where the air quality does not comply with the directive, which poses a challenge due to the use of different models and protocols in different European countries. The APPRAISAL EU FP7 project (Thunis et al., 2016) brought together experts from different countries to establish a database considering the synergies among different regions, air quality evaluation, health impact assessment, source apportionment and uncertainties.

In South Asia, the surface and vertical transport of ozone is controlled by the monsoon circulation, as shown with the use of air quality modelling by Surendran et al. (2015). Wang and Hao (2012), analysing the air quality situation in China, estimated that the emissions of pollutants should decrease by an average of $50 \%$ in order to conform to the ambient air quality guidelines proposed by the WHO.

The objective of this review was to synthesise the latest information on particulate matter (PM) and ozone formation in the study domain, analysing their source strengths 
and emissions, the current state of the art for their characterisation, as well as for air quality modelling, and the regulatory approaches to limiting their probable effects on human health and climate change in the MASP. In addition, we address the historical significance of policies, regulations and interventions. We also highlight research gaps and suggest future priorities to fill those gaps. Other studies have concentrated on the analysis of the air quality in the MASP by focusing on vehicular emissions and their impacts on the air quality, such as those conducted by Carvalho et al. (2015) and PerezMartinez et al. (2015). Both of those studies presented the evolution of the concentrations of the regulated pollutants since 2000. To our knowledge, this is the first comprehensive review article that brings together a number of technical aspects related to PM, including fine particles, and its chemical composition, together with ozone formation in the MASP in general.

\section{Scope, aims and outline}

This review focuses on the MASP, which is the largest urban area in Brazil, and on two pollutants: $\mathrm{PM}$ in different size ranges, including $\mathrm{PM}_{10}, \mathrm{PM}_{2.5}$ and ultrafine particles (UFPs, defined as particles below $100 \mathrm{~nm}$ in diameter); and ozone. Although PM is of greater importance from a health perspective, ozone is the only pollutant in the MASP which shows a consistent trend toward an increase (Perez-Martinez et al. 2015; Carvalho et al. 2015), due to the use of large quantities of fossil fuels and biofuels (biodiesel and ethanol). Therefore, aspects related to both of these pollutants are reviewed in detail.

\section{Historical perspectives on policies, regulations and interventions}

The first air pollution measurements in the MASP were taken in late 1960s with a network for $\mathrm{PM}$ and $\mathrm{SO}_{2}$ monitoring, with technical and financial support from the Pan American Health Organization and the WHO. In 1975, CETESB was charged with monitoring air pollution and an air quality monitoring network was established. The monitoring of $\mathrm{SO}_{2}$ emissions by stationary sources began in 1982, with the use of less sulfur in fuel oil and the replacement of fuel oil with electricity or natural gas. Motivated by the complaints of the population, the control of emissions from the major sources became mandatory. The decrease in $\mathrm{SO}_{2}$ concentrations was attributed to the regulation of the stationary sources and, in the 1990s, of the sulfur content in diesel fuel. 
Those interventions resulted in a consistent decrease in $\mathrm{SO}_{2}$ concentrations, as can be seen in Figure 1.

In 1975, in response to an increase in the international price of the oil and a decline in sugar prices, the National Ethanol Program was created. The Program required the initial use of $10 \%$ anhydrous ethanol as an additive to gasoline, or the option of having modified spark-ignition engines running exclusively on hydrated ethanol (95\% ethanol $+5 \%$ water).

The proportion of anhydrous ethanol in the blend has increased over the years and is currently at $27 \%$. The first effect of that was a decrease in the concentration of lead $(\mathrm{Pb})$ in the atmosphere. The production of vehicles designed to run on ethanol increased when subsidies and other factors reduced the cost of ethanol. However, in 1980, the international price of oil decreased. During that same period, off-shore and natural oil reserves were discovered in Brazil. In 1993, to maintain the levels of ethanol use, a law was created to impose the use of gasohol, rather than gasoline. Emission standards for motor vehicles in the MASP are determined by the PROCONVE, established in 1983, which has defined increasingly restrictive standards, especially for emissions of CO, VOCs, $\mathrm{NO}_{x}$ and $\mathrm{PM}_{10}$ (CETESB, 2014).

As the transport sector became the main actor for pollutant emissions, the PROCONVE became the main driver for reducing air quality violations in Brazilian cities. The PROCONVE was implemented in phases, and the decrease in vehicle emissions has been accompanied by an enforceable law to reduce pollutants, to promote the largescale use of biofuels, such as ethanol and biodiesel, and to reduce the sulfur content in fuels. The program dedicated to LDVs, designated phase L1, was initiated in 1988, and each subsequent phase has been more restrictive than the one before. Currently, the LDV program is in phase L6. For CO, $\mathrm{HC}$ and $\mathrm{NO}_{x}$, respectively, the emission limits for new LDVs decreased from 24, 2.1 and $2 \mathrm{~g} / \mathrm{km}$ in phase L2 to $12.0,1.2$ and $1.4 \mathrm{~g} / \mathrm{km}$ in phase L3; 2.0, 0.16 and $0.25 \mathrm{~g} / \mathrm{km}$ in phase L4; 2.0, 0.05 and $0.12 \mathrm{~g} / \mathrm{km}$ in phase L5; and 1.3, 0.05 and $0.08 \mathrm{~g} / \mathrm{km}$ in phase L6. Efforts to reduce the emission of pollutants by heavy-duty vehicles (HDVs) were delayed in Brazil. Although PROCONVE regulations for HDVs were established in 1990, there were no legally imposed limits for gaseous or particulate emissions during phases 1 and 2 (P1 and P2, respectively). However, in phase P3, limits of 4.9, 1.23, 9.0 and $0.4 \mathrm{~g} / \mathrm{kWh}$ were imposed for $\mathrm{CO}, \mathrm{HC}, \mathrm{NO}_{x}$ and $\mathrm{PM}$, respectively. Phase $\mathrm{P} 4$ was more restrictive, an emission limit of $0.15 \mathrm{~g} / \mathrm{kWh}$ being 
imposed for PM, as well as limits of 4.0, 1.1 and $7 \mathrm{~g} / \mathrm{kWh}$, respectively, for $\mathrm{CO}, \mathrm{HC}$ and $\mathrm{NO}_{x}$. In phase P5, the emission of $\mathrm{CO}$ was limited to $2.1 \mathrm{~g} / \mathrm{kWh}$, whereas those of $\mathrm{HC}$, $\mathrm{NO}_{x}$ and PM were limited to $0.66,5.0$ and $0.10 \mathrm{~g} / \mathrm{kWh}$, respectively. In phase $\mathrm{P} 6$, the limits were reduced to $0.02 \mathrm{~g} / \mathrm{kWh}$ for $\mathrm{PM}, 3.5 \mathrm{~g} / \mathrm{kWh}$ for $\mathrm{NO}_{x}, 0.46 \mathrm{~g} / \mathrm{kWh}$ for $\mathrm{HC}$ and $1.5 \mathrm{~g} / \mathrm{kWh}$ for CO. The implementation of phase P6 was postponed due to delays in the specification of the fuel (diesel) to be sold in Brazil. That resulted in a similar postponement in the implementation of phase P7, which consequently did not occur until 2012. In phase $\mathrm{P} 7$, an emission limit of $2 \mathrm{~g} / \mathrm{kWh}$ was imposed for $\mathrm{NO}_{x}$, which increased the availability and enabled the commercialization of S-10, a diesel fuel with a sulfur content of $10 \mathrm{ppm}$ (Nogueira et al., 2015a). In phase P7, the emissions standards for CO, HC and PM remained the same as they had been in phase P6. All PROCONVE phases are presented in Figure 1.

The PROCONVE standards are based on the standard emission factors for new vehicles established by the US Environmental Protection Agency (USEPA), which differ slightly from those established by the European Union. Although the PROCONVE had imposed mandatory emissions limits in 1986, some regulations for truck and bus emissions were not imposed until the 1990s. In addition, as part of the old fleet continues to run, the average emissions are higher than the established limits.

The average LDV on the road in 2003 in Brazil still emitted approximately $12.3 \mathrm{~g} . \mathrm{km}^{-1}$ of CO (CETESB, 2004). The emission values and their relationship to the concentrations of $\mathrm{CO}$ and $\mathrm{NO}_{x}$ are presented in supplementary material (S1).

In Figure 1 is also presented, since 1980, the concentration of the regulated pollutants $\mathrm{CO}, \mathrm{PM}_{10}, \mathrm{O}_{3}, \mathrm{SO}_{2}$ and $\mathrm{NO}_{2}$ (nitrogen dioxide) for some air quality stations and the number of vehicles that run on ethanol, gasohol, diesel and those which are flex-fuel vehicles (run with gasohol or ethanol), the indication of the periods when each phase of the program for controlling the emissions is also presented. 


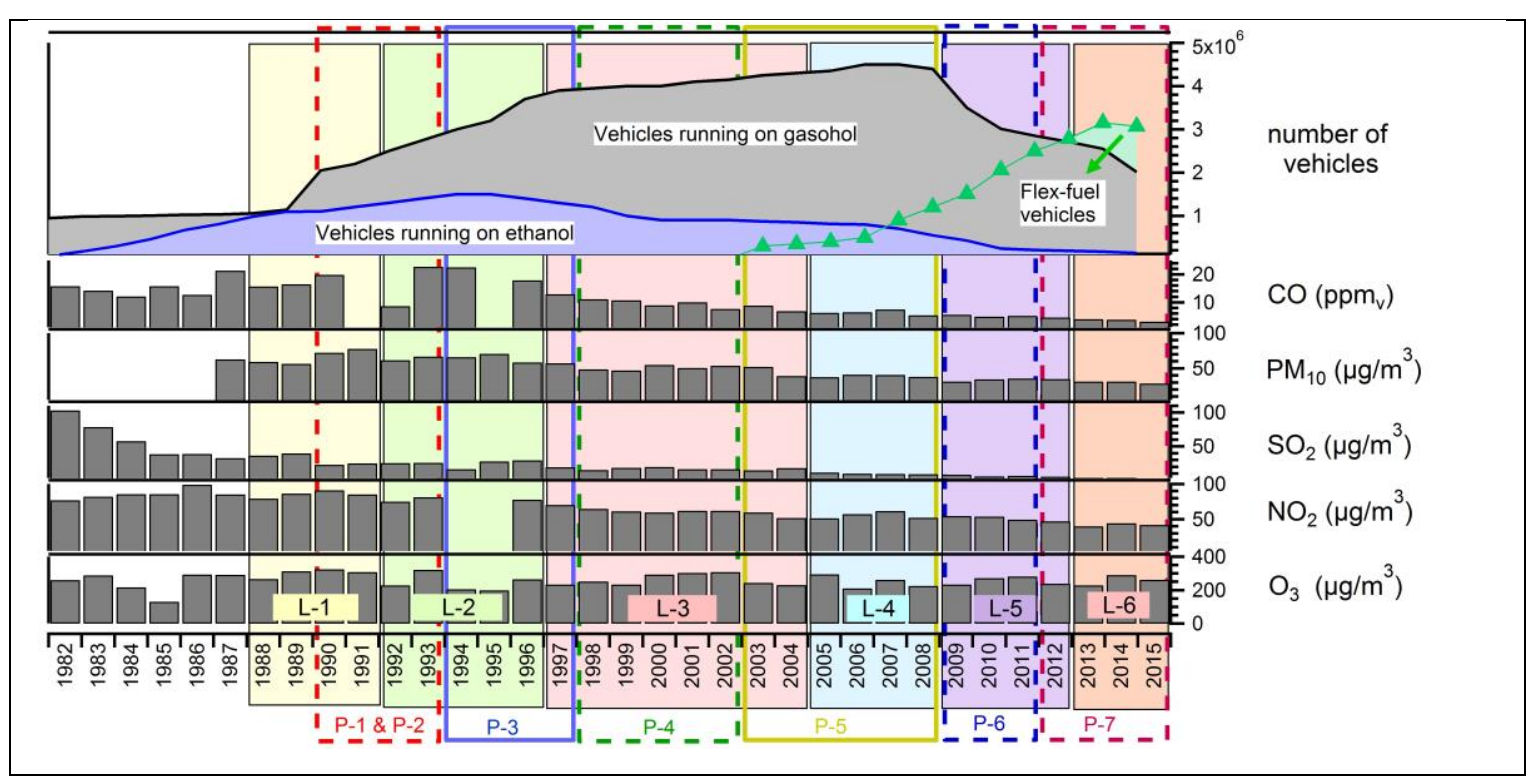

Figure 1: Evolution of the average values of $\mathrm{CO}, \mathrm{PM}_{10}, \mathrm{O}_{3}, \mathrm{SO}_{2}$ and $\mathrm{NO}_{2}$ concentrations measured at the CETESB air quality monitoring stations in the MASP, number of vehicles by category (gasohol, ethanol and diesel) and the year of implementation of the Programa de Controle da Poluição do Ar por Veículos Automotores (PROCONVE, Program for the Control of Air Pollution Emissions by Motor Vehicles) phases.

The figure illustrates the direct impact of the implementation of the programs for emission control, with a substantial decrease in the concentrations of $\mathrm{PM}_{10}, \mathrm{SO}_{2}$ and $\mathrm{NO}_{2}$ since the 1990s. In 1990, the air quality standards were revised to include the concept of primary and secondary standards. Perez-Martinez et al. (2015) and Carvalho et al. (2015) performed a detailed analysis of the temporal variation of the regulated pollutants due to the changes in fuels, engines and air quality standards.

The Brazilian Conselho Nacional do Meio Ambiente (CONAMA, National Environmental Council) was created in 1981, during a period that was initially marked by a political and cultural environment that envisioned development at any cost. Since then, the CONAMA achieved its consolidation and established itself as a standard in the context of practices related to sustainable development. Its composition is decided by federal power and includes representatives from all of the Brazilian states (including the Federal District of Brasília) and, apart from the elected members and those appointed by the most representative entities of the economy, including the industrial and agricultural sectors, members that represent civil society through environmental entities of the Republic, and the Federal Government through its main Ministries. 
Air quality standards are objectives that should be reached through control strategies set by emission standards and must serve as guidelines for the creation of regional air pollution control plans. In 1990, the CONAMA set national ambient air quality standards for seven principal pollutants (CONAMA Resolution no. 3, June 28, 1990). According to the Resolution, primary air quality standards are pollutant concentrations that if surpassed may be hazardous to the health of the population, whereas secondary air quality standards are pollutant concentrations that if surpassed can have any adverse effects on the well-being of the population or even minimal effects on the fauna, flora, goods and the environment in general. The current primary air quality standards are listed in Table 1. 
Table 1. Primary air quality standards ${ }^{\text {a }}$, for Brazil as a whole and for the state of São Paulo, together with the WHO Guidelines, American national air quality standard and European Commission standard.

\begin{tabular}{|c|c|c|c|c|c|c|c|c|c|c|}
\hline & & $\mathrm{PM}_{2.5}$ & $\mathrm{PM}_{10}$ & TSP & $\mathrm{SO}_{2}$ & $\mathrm{NO}_{2}$ & Ozone & $\mathrm{CO}$ & $\mathrm{Pb}$ & Smoke \\
\hline \multirow[t]{2}{*}{$\begin{array}{l}\text { Brazilian standard } \\
\text { (CONAMA no. 03/90) }\end{array}$} & $\begin{array}{l}\text { Short-term } \\
\text { exposure }\end{array}$ & - & $150^{b}(24 h)$ & $240^{\mathrm{b}}(24 \mathrm{~h})$ & $365^{b}(24 h)$ & $320(1 \mathrm{~h})$ & $160^{b}(1 \mathrm{~h})$ & $\begin{array}{l}10,000^{b}(8 \mathrm{~h}) \\
40,000^{\mathrm{b}}(1 \mathrm{~h})\end{array}$ & - & $150^{b}(24 h)$ \\
\hline & $\begin{array}{l}\text { Long-term } \\
\text { exposure }\end{array}$ & - & $50\left(\right.$ year $\left.^{c}\right)$ & 80 (year $\left.^{d}\right)$ & 80 (year $^{c}$ ) & $100\left(\right.$ year $\left.^{c}\right)$ & - & - & - & 60 (year $\left.^{c}\right)$ \\
\hline \multirow[t]{2}{*}{$\begin{array}{l}\text { Standard for the state } \\
\text { of São Paulo }\end{array}$} & $\begin{array}{l}\text { Short-term } \\
\text { exposure }\end{array}$ & $60(24 \mathrm{~h})$ & $120(24 \mathrm{~h})$ & $240(24$ h) & $60(24 \mathrm{~h})$ & $\mathbf{2 6 0}(1 \mathrm{~h})$ & $140(8 \mathrm{~h})$ & 9 ppmv (8 h) & - & $120(24 \mathrm{~h})$ \\
\hline & $\begin{array}{l}\text { Long-term } \\
\text { exposure }\end{array}$ & $20\left(\right.$ year $\left.^{c}\right)$ & $40\left(\right.$ year $\left.^{c}\right)$ & $80\left(\right.$ year $\left.^{c}\right)$ & 40 (year $\left.{ }^{c}\right)$ & 60 (year $\left.{ }^{c}\right)$ & - & - & 0.5 (year $\left.^{b}\right)$ & $40\left(\right.$ year $\left.^{c}\right)$ \\
\hline \multirow[t]{3}{*}{ WHO guidelines } & Short-term & $25(24 \mathrm{~h})$ & $50(24 \mathrm{~h})$ & - & $20(24 \mathrm{~h})$ & $200(1 \mathrm{~h})$ & $100(8 \mathrm{~h})$ & $10,000(8 \mathrm{~h})$ & - & - \\
\hline & exposure & & & & $500(10 \mathrm{~min})$ & & & $30,000(1 \mathrm{~h})$ & & \\
\hline & $\begin{array}{l}\text { Long-term } \\
\text { exposure }\end{array}$ & $10\left(\right.$ year $\left.^{c}\right)$ & $20\left(\right.$ year $\left.^{c}\right)$ & - & - & $40\left(\right.$ year $\left.^{\mathrm{c}}\right)$ & - & - & - & - \\
\hline \multirow[t]{2}{*}{$\begin{array}{l}\text { American national } \\
\text { standard }\end{array}$} & $\begin{array}{l}\text { Short-term } \\
\text { exposure }\end{array}$ & $35\left(24 \mathrm{~h}^{\mathrm{e}}\right)$ & $150(24 \mathrm{~h})$ & - & $75 \operatorname{ppbv}\left(1 \mathrm{~h}^{\mathrm{h}}\right)$ & $100 \operatorname{ppbv}\left(1 \mathrm{~h}^{\mathrm{i}}\right)$ & $0.07 \mathrm{ppm}\left(8 \mathrm{~h}^{\mathrm{j}}\right)$ & $\begin{array}{l}9 \operatorname{ppmv}\left(8 \mathrm{~h}^{\mathrm{b}}\right) \\
35 \operatorname{ppmv}\left(1 \mathrm{~h}^{\mathrm{b}}\right)\end{array}$ & $\begin{array}{l}0.15 \text { (3 month } \\
\text { average) }\end{array}$ & - \\
\hline & $\begin{array}{l}\text { Long-term } \\
\text { exposure }\end{array}$ & 12 (year $\left.{ }^{f}\right)$ & - & - & - & 53 ppbv (year ${ }^{c}$ ) & - & - & - & - \\
\hline \multirow[t]{2}{*}{$\begin{array}{l}\text { European Commission } \\
\text { standard }\end{array}$} & $\begin{array}{l}\text { Short-term } \\
\text { exposure }\end{array}$ & - & $50(24 \mathrm{~h})$ & - & $\begin{array}{c}350(1 \mathrm{~h}) \\
125(24 \mathrm{~h})\end{array}$ & $200(1 \mathrm{~h})$ & $120\left(8 \mathrm{~h}^{\mathrm{k}}\right)$ & $10 \mathrm{mg} / \mathrm{m}^{3}\left(8 \mathrm{~h}^{\mathrm{g}, \mathrm{k}}\right)$ & - & - \\
\hline & $\begin{array}{l}\text { Long-term } \\
\text { exposure }\end{array}$ & 25 (year $^{\mathrm{g}}$ ) & $40\left(\right.$ year $\left.^{\mathrm{g}}\right)$ & - & - & 40 (year $^{\mathrm{g}}$ ) & - & & 0.5 (year $^{\mathrm{g}}$ ) & - \\
\hline
\end{tabular}


After 26 years, the Brazilian national air quality standard has yet to be revised. As a consequence, two Brazilian states (São Paulo and Espirito Santo) decided to implement local air quality standards. The state of São Paulo changed its regulation in 2013 to include standards for fine particles and more restrictive values for other pollutants, as shown in Table 1. Comparing the Brazilian standards, it is possible to observe that there is not a significant difference between the local standards (for the state of São Paulo) and the national standard. In addition to including new pollutants, such as $\mathrm{PM}_{2.5}$, in the local standards, the main objective was to comply with the WHO guidelines. However, following the WHO recommendation, which says that to facilitate the implementation of their guidelines, especially in more polluted areas, local authorities should set interim targets which, if achieved, would result in significant reductions in pollutant-related health risks and would indicate progress toward the guideline values. Table 1 shows only the values for the first interim target implemented in the state of São Paulo in 2013. Two more intermediate interim targets must be hit before the WHO guideline standard can be met.

Comparing the two Brazilian standards with those of the USEPA and the European Commission, it is possible to find similar values for some pollutants. For instance, the maximum concentration of $\mathrm{PM}_{2.5}$ is approximately two times higher in the standard for the state of São Paulo than in the USEPA standard and approximately the same as in the European Commission standard for long-term exposure. In contrast, the maximum concentration of $\mathrm{PM}_{10}$ in the São Paulo standard $\left(120 \mu \mathrm{g} \cdot \mathrm{m}^{-3}\right)$ is more restrictive than that stipulated in the USEPA standard $\left(150 \mu \mathrm{g} \cdot \mathrm{m}^{-3}\right)$. For short-term exposure to $\mathrm{PM}_{10}$, the European Commission standard has the same value as that listed in the WHO guidelines $\left(50 \mu \mathrm{g} \cdot \mathrm{m}^{-3}\right)$, which is quite restrictive and difficult to implement in Brazil, without a previous control, because of the high influence of large particles emitted by resuspended soil, biogenic sources and marine sources.

The implementation of the Programa de Controle de Emissões de Motocicletas (PROMOT, Program for the Control of Emissions by Motorcycles) was an important step toward bringing motorcycle emissions in line with those already mandated for the light-duty fleet. Under current Brazilian law, a motorcycle can emit 10 times more pollutants than can a car manufactured in the same year. In the MASP, motorcycles are responsible for $22 \%$ and $12 \%$ of CO and HC emissions, respectively (CETESB, 2015). Slowly shifting the current motorcycle fleet to e-bikes, such as those used in Beijing ( Ji 
et al., 2012), could bring substantial benefit to efforts to control emissions from this important emission source. In addition, routine inspection is important to ensure strict enforcement of the legislation related to most vehicles.

A local program for reducing the emissions in the city of São Paulo was the implementation, in 1996, of the system known as the rodizio, in which each passenger car is prohibited from being on the road one day per week (Jacobi et al., 1999). However, in 1997, the program was changed to contemplate traffic congestion, and passenger cars have since been prohibited from being on the road only during peak hours (7-10 am and 5-8 pm), still one day per week. In 2009, the same program was extended to trucks (diesel-powered vehicles), which promoted a different hourly emission profile. The introduction of a congestion charge, as has been imposed in central London and Singapore, has led to a reduction in congestion as well as in traffic casualties, together with a reduction in car trips, a shift in departure times and a switch to public transport (Santos, 2005; Li and Hensher, 2012). A similar trial was conducted recently in Delhi, in the form of odd-even car experiment. The Delhi alternate-day car ban, in which vehicles with odd-numbered plates are allowed to run only on odd dates and was intended to keep $20 \%$ of the cars off the road. After exemptions for categories such as women drivers, emergency vehicles, disabled drivers, the proportional reduction in the number of cars on the road is equivalent to only approximately $6 \%$. Reports are thus far divided on its effectiveness in terms of pollution reduction, although it produced improvements in traffic congestion similar to those seen in São Paulo. Silva et al. (2012) estimated the benefits of the current transportation system in the MASP in monetary terms, based on the air quality-related diseases avoided.

Concerning long-range transport sources, sugarcane cultivation, which is the main agricultural activity in the state of São Paulo, is a major contributor. The pre-harvest burn-off of the bagasse is under regulation and is scheduled to be banned completely in 2017.

\section{Sources and emissions}

\subsection{Local vehicular sources}

The MASP is currently characterised by local emissions of its mobile sources. According to CETESB, road traffic accounts for $97.5 \%$ of $\mathrm{CO}$ emissions, $79 \%$ of $\mathrm{HC}$ emissions, $67.5 \%$ of nitrogen oxide $\left(\mathrm{NO}_{x}\right)$ emissions, $22 \%$ of $\mathrm{SO}_{2}$ emissions and $40 \%$ of $\mathrm{PM}_{10}$ emissions (CETESB, 2015). Figure 2 shows the total $\mathrm{CO}, \mathrm{NO}_{x}, \mathrm{HC}$ and $\mathrm{PM}_{10}$ 
emissions, according to the official inventory for the MASP. The large amount of biofuels used in the MASP makes this region an important example of the atmospheric chemistry of fossil fuel and biofuel emissions. The 7 million vehicles run on gasohol, ethanol or diesel (the last mostly for trucks and buses). The total fuel consumption in the MASP is illustrated in Figure 3. Of all vehicles in the MASP, 85\% are LDVs (e.g. passenger cars) running on gasohol or hydrated ethanol, 3\% are HDVs (e.g. trucks and buses) running on diesel, and $12 \%$ are motorcycles running on gasohol.

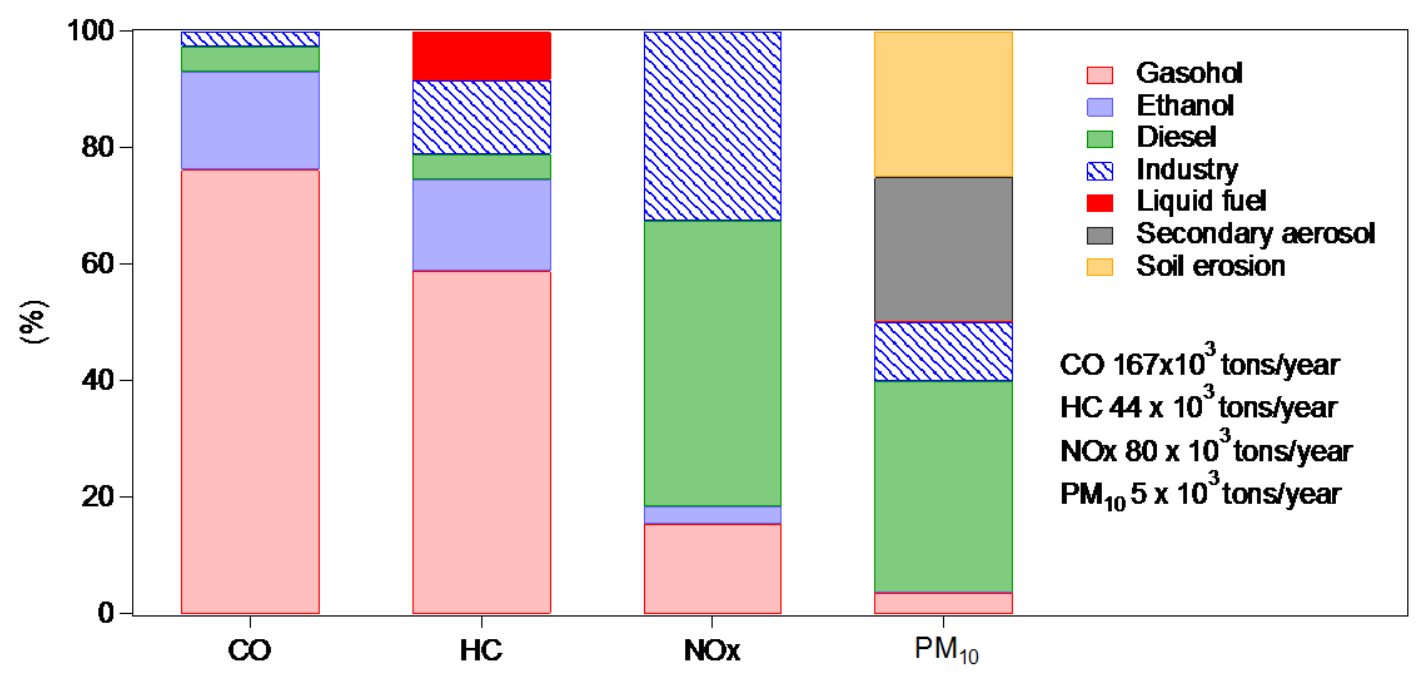

Figure 2: State official source inventory for the year of 2015, in the Metropolitan Area of São Paulo, in tons $\mathrm{yr}^{-1}$ (adapted from CETESB, 2015).

Since 2003, the number of flex-fuel vehicles has been increasing, their operators choosing to use gasohol or ethanol according to the respective prices of the two. Since 2013, the use of S10 diesel fuel has been mandatory for new diesel motors, although old trucks and buses can still run on S500. All diesel fuel is a blended with 8\% biodiesel (mainly containing biodiesel from soybeans).

In the 1980s and 1990s, many industries moved their operations to other cities with fewer restrictions on the installation of new, potentially polluting, industries. Therefore, local industrial emissions currently make only a small contribution to the concentrations of air pollutants in the MASP. 


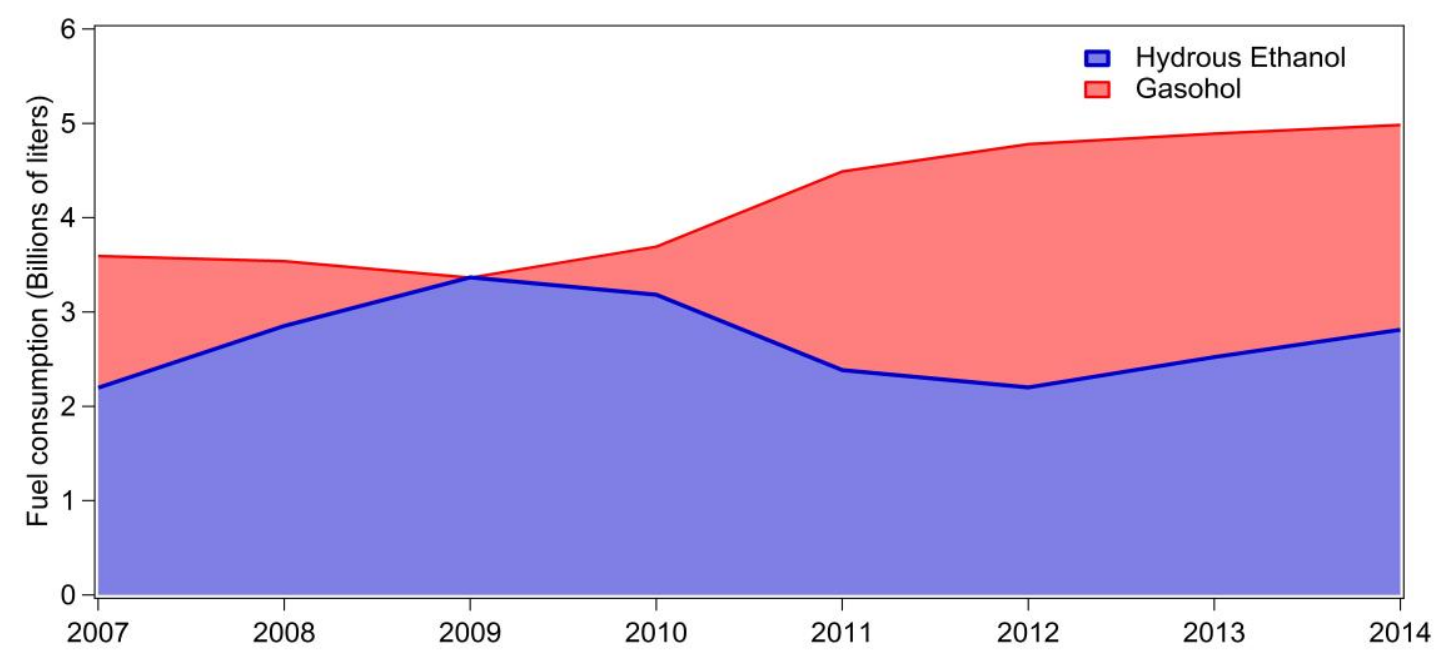

Figure 3: Fuel consumption in the MASP. Source: Petroleum, Natural Gas, and Biofuels National Agency (ANP, 2016).

In addition to the regulated sources mentioned above, a variety of air pollutants are emitted from numerous unregulated sources in the MASP, such as gas stations, bakeries, restaurants and pizzerias, as well as from the burning of coal during outdoor grilling and from civil construction activities, contributing to the local air pollution (Kumar et al., 2016). For example, there are 8,000 pizzerias in São Paulo and approximately $80 \%$ of them use ovens that burn wood, mainly eucalyptus (Lima, 2015), which are important contributors to PM, especially under stable atmospheric conditions. Waked et al. (2015) also found that outdoor grilling was a major contributor to PM in Lebanon, accounting for more than $30 \%$ of total organic carbon (OC) concentrations. The contributions that these unregulated sources make to air pollution in the MASP have yet to be quantified. Oyama et al. (2015) stated that primary biomass burning contributed 10-30\% of all carbonaceous aerosols in the atmosphere of the MASP, sugarcane burning accounting for up to $15 \%$ of the OC concentration. Local sources of emissions from the burning of wood and charcoal have been shown to represent no more than $3 \%$ of the PM emitted in the MASP (Kumar et al., 2016).

Despite the increase in the number of vehicles and in the consumption of fuels, pollutant concentrations have decreased in the last ten years, the only exceptions being those of ozone and $\mathrm{PM}_{2.5}$. It should be noted that, unlike other pollutants, for which hourly pollutant concentrations have been recorded (by CETESB) since 1996, $\mathrm{PM}_{2.5}$ has been monitored only since 2005. Carvalho et al. (2015) and Perez-Martinez et al. (2015) showed the impact of implementing programs for controlling the vehicular emissions, 
establishing emissions factors more restricted and in accordance with international standards. Two programs - PROCONVE and PROMOT_-imposed emission factors for each category of vehicle, including LDVs, HDVs and motorcycles.

\subsection{Influence of other local and external sources}

In addition to local sources, the ambient air quality of each city is affected by the pollutants originating outside the city and transported to its airshed. External sources such as sugarcane burning and forest fires upwind of the MASP during certain months of the year contribute to pollution episodes in the MASP. Brazil is the world's largest producer of sugarcane, with a sugarcane cultivation area of 7.8 million hectares, accounting for $2.3 \%$ of the arable land in the country and producing approximately 490 $\left(\times 10^{6}\right) \mathrm{kg} \mathrm{yr}^{-1}$ (http://www.agricultura.gov.br/servicos-e-sistemas/sistemas/Sapcana). Burning of sugarcane residue during the May-October period has clear effects on local air quality by affecting PM chemical composition in the MASP (Allen et al., 2009; Souza et al., 2014; Vasconcellos et al., 2010). During the burning period, air masses from the areas of biomass burning circulate over the sea and over the biggest industrial park in the state (Cubatão, a city with chemical, pharmaceutical, petrochemical, steel and fertiliser manufacturing, among other activities) prior to reaching the MASP (Vasconcellos et al., 2010). A number of dedicated field campaigns, such as AMAZE08 (Martin et al., 2010) and GoAmazon2014/5 (Martin et al., 2015), have been carried out to quantify the impact of biomass burning on air quality and climate in the Amazon region and downwind areas. Those studies concluded that emissions from biomass burning on the southern edge of the forest can be transported southward and southeastward across the Atlantic coast of Brazil and should be included in the quantitative assessments of urban air pollution. Although the impact of biomass burning can be observed in the $\mathrm{PM}_{2.5}$ composition (Miranda et al., 2017), its participation is not easily quantified, due to local emissions from the burning of residue, wood and charcoal (Kumar et al., 2016). Souto-Oliveira et al. (2016) studied the behaviour of black carbon and chlorine as tracers for the transport from the southeast (coastal region) and northwest (agricultural region), as well as the impact of those air masses on new particle

formation. Oyama et al. (2015), through analysis of the ${ }^{14} \mathrm{C}$ values measured inside road tunnels, showed that most of the elemental carbon (EC) and OC are related to the fuels used in the transportation system. The ambient EC was attributed to two main sourcesvehicular emissions and biomass burning, vehicular sources accounting for roughly 
$90 \%$ of EC during weekdays and $80 \%$ of EC during weekends - whereas the OC concentrations were found to be dominated by secondary carbon from vehicular emissions. The authors concluded that, in the MASP, biomass burning accounts for 10$30 \%$ of the total carbonaceous aerosols $(\mathrm{EC}+\mathrm{OC})$ and that sugarcane burning could account for up to $15 \%$ of the $\mathrm{OC}$, based on ${ }^{13} \mathrm{C}$ and ${ }^{14} \mathrm{C}$ measurements.

\section{Characterisation of pollutants}

\subsection{Ozone}

Tropospheric ozone is produced from the photochemical oxidation of pollutants from vehicular emissions, which are responsible for approximately 97\%, 79\% and $67 \%$ of emissions of $\mathrm{CO}, \mathrm{HC}$ and $\mathrm{NO}_{x}$, respectively. Diesel engines in HDVs, such as buses and trucks, emit more than $40 \%$ of $\mathrm{NO}_{x}$ (CETESB, 2016). In addition, large quantities of ethanol are burned in Brazil, accounting for 19\% of the total fuel used in vehicles in the country (ANP, 2016) and for nearly 50\% of that used in the MASP. As a consequence, relatively high concentrations of acetaldehyde are found in the MASP. Ethanol contributes to ozone formation in the MASP in two ways: the emissions of acetaldehyde as a result of the incomplete combustion of ethanol, which has high ozone-forming potential; and the direct evaporative emission of ethanol despite its low ozone-forming potential and reactivity. In the atmosphere, ethanol forms acetaldehyde and peroxyacetyl nitrate by photo-oxidation and oxidation processes, which take several hours.

Recent studies have suggested that ozone concentrations in the MASP can be reduced by the owners of flex-fuel cars shifting from ethanol to gasohol (Martins and Andrade, 2008a). Two recent studies (Madronich, 2014; Salvo and Geiger, 2014) suggested that a switch from ethanol to gasoline use in São Paulo, in response to changing prices, led to lower local levels of ozone pollution. Studies conducted in other cities around the world have demonstrated the same adverse effect of ethanol on ozone concentrations. For example, Jacobson (2007) analysing simulations scenarios for August 2020, found that the use of a fuel containing $85 \%$ ethanol and $15 \%$ gasoline increased concentrations of ozone (from 0.8 to $1.4 \mathrm{ppbv}$ in Los Angeles and from 0.3 to $0.6 \mathrm{ppbv}$ in the United States as a whole), which led to increases in the mortality rates (120 deaths $\mathrm{yr}^{-1}$ and 185 deaths $\mathrm{yr}^{-1}$, respectively in Los Angeles and in the United States as a whole) and hospitalisation rates (by 645 admissions $\mathrm{yr}^{-1}$ and by 988 admissions $\mathrm{yr}^{-1}$, in Los Angeles and United States, respectively). In addition, Ginnebaugh and Jacobson (2012) 
showed that at low temperatures that same fuel $(85 \%$ ethanol; $15 \%$ gasoline) can enhance ozone production significantly more than does gasoline.

Ozone concentrations in the MASP decreased between 1996 and 2006. For example, at one CETESB air quality monitoring station (Ibirapuera), the maximum 1-h ozone concentration ( $\max 1$-h ozone) was $374 \mu_{\mathrm{g} \mathrm{m}}^{-3}$, reached on 44 days, in 1996, whereas the max 1-h ozone was $225 \mu \mathrm{g} \mathrm{m}^{-3}$, reached on 18 days, in 2006. Figure 4 presents the two highest (first and second) hourly concentrations recorded in each year at the Ibirapuera station, showing that after 2006, an upward trend was observed in the maximum 1-h ozone concentrations as well as in the number of days on which the national air quality standard was exceeded. For example, in 2015, the max 1-h ozone was $268 \mathrm{\mu g} \mathrm{m}^{-3}$ and was reached on 28 days, a higher concentration and greater number of days than in 2006. Therefore, it is necessary to understand the influential factors underlying the upward trend in ozone concentrations since 2006.

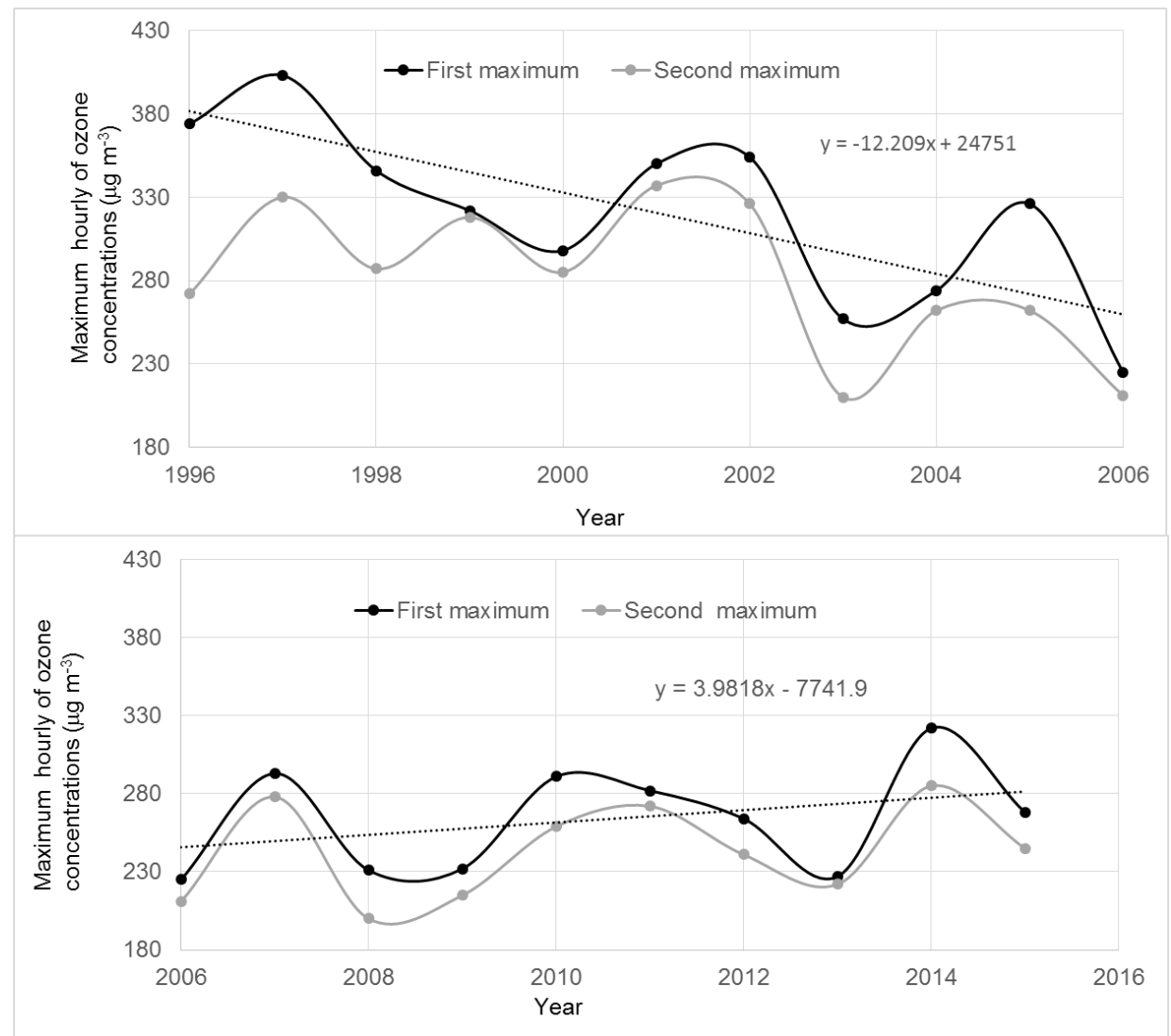

Figure 4: First and second maximum concentrations of hourly ozone at the CETESB Ibirapuera air quality monitoring station, from 1996 to 2015. 
In a $\mathrm{NO}_{x}$-inhibited regime, the decrease in $\mathrm{NO}_{x}$ emissions, mainly from $\mathrm{HDV}$ vehicles, could also influence the production of ozone (Madronich, 2014). This largely agrees with the findings of studies showing that simultaneous decreases in the emissions of $\mathrm{NO}_{x}$ and $\mathrm{CO}$ are greater on weekends than on weekdays, whereas the inverse is true for ozone levels (Marr and Harley, 2002a, 2002b; Harley et al., 2005; Gentner et al., 2009). In a study conducted in the United States, Stedman (2004) also concluded that reductions in $\mathrm{CO}$ and $\mathrm{HC}$, both of which are ozone precursors, would lead to stable or even increasing ozone levels due to a simultaneous reduction in $\mathrm{NO}_{x}$ emissions.

Initial studies of ozone production in the MASP analysed the seasonal behaviour of ozone and its precursors, as well as secondary nocturnal peaks. Massambani and Andrade (1994) reported two ozone peaks in the MASP, the first between 14:00 and 15:00 local standard time (LST) and the second (a nocturnal peak) between 3:00 and 4:00 LST, the second peak being related to the vertical transport of ozone and its precursors from the residual layer. In another study, Guerrero (2016) analysed the occurrence of nocturnal secondary ozone peaks in the MASP using ten years of hourly data and found that the secondary ozone peak occurred around 4:00 LST, which was related to downward transport of ozone (from aloft to the surface). Guardani et al. (1999) used a neural network to study atmospheric ozone formation in the MASP and found that temperature was the main driver of ozone formation.

Boian and Andrade (2012) examined the contributions of local and remote sources to the concentration of ozone by evaluating the interactions of ozone transport between the Metropolitan Area of Campinas (MAC, $100 \mathrm{~km}$ northwest of the MASP) and the MASP. They reported that ozone concentrations in the MAC are associated with local emissions, together with the transport of ozone and its precursors from the MASP.

Biogenic emissions are known to have a large impact on the ozone formation, due to the high reactivity of isoprene and terpenes, both of which are related to the production of reactive biogenic VOCs (BVOCs). Using air quality modelling, Martins et al. (2006) studied the impact of BVOCs on photochemical oxidant formation in the MASP during winters of 1999 and 2000. The authors found that BVOCs could contribute to an increase in concentrations of ozone and peroxyacetyl nitrate. The atmosphere chemical regime of ozone formation is an important factor in the estimation of this contribution. Using an air quality model, Sánchez-Ccyollo et al. (2006a) evaluated the impacts of reactive $\mathrm{HC}(\mathrm{RHC})$ and $\mathrm{NO}_{x}$ on ozone formation, as well the meteorological variables. They found that reductions in RHC emissions could provide the best scenario for 
lowering ozone concentrations in the MASP. Martins and Andrade (2008b) evaluated the VOC potentials for ozone formation using a three-dimensional air quality model and found that aromatics, olefins, ethane and formaldehyde are the most important contributors to ozone formation in the MASP. In addition, they confirmed that the ozone formation in the MASP is more sensitive to changes in VOC emissions than to changes in $\mathrm{NO}_{x}$ emissions (i.e. ozone in the MASP is VOC-limited).

\subsection{Ozone precursors}

It is well known that VOCs (especially carbonyls and unsaturated HC; e.g. alkenes) are major precursors of ozone formation (Atkinson, 2000; Jacob, 2000), and that every VOC has a different level of photochemical reactivity. Dominutti et al. (2016) showed that there has been a decrease in HC concentrations over the last decade in the MASP, particularly for aromatics, which diminished by a factor of 2.3 at urban-traffic sites and by a factor of 4 at urban-background sites. It is noteworthy that there was a marked decrease in those concentrations in the MASP between 2006 and 2008, which is consistent with the increase in ethanol consumption and in the number of flex-fuel vehicles, the only exception being ethylene, the concentrations of which were higher in 2008 than in 2006. These results are in accordance with those of studies showing a decrease in aromatic compounds and an increase in tailpipe ethylene emissions when ethanol is added to gasoline (Poulopoulos et al., 2001; Niven, 2005).

A reduction in VOC concentrations was also observed for aldehydes (Martins et al., 2008c; Nogueira et al., 2014, Nogueira et al., 2015b), the major VOC being emitted from ethanol combustion. Aldehyde concentrations obtained inside traffic tunnels in the MASP over the last 20 years confirm the assertion that vehicles in Brazil have emitted fewer and fewer aldehydes over the years. The reduction in aldehyde emissions was largely due to the implementation of new vehicle technologies. During the 1980s, most Brazilian vehicles did not use catalytic systems for the conversion of exhaust gases and the engines were inefficient. Since 2003, flex-fuel vehicles available on the Brazilian market have had modern three-way catalytic converters. The monitoring of aldehyde emissions by new cars has also contributed to that reduction (Nogueira et al., 2015a). For vehicles running in the MASP in 2011, carbonyl emissions from HDVs had greater ozone-forming potential on a per-km-travelled basis than did those from LDVs (Nogueira et al., 2015b). For both vehicle types, the largest carbonyl contributors to ozone production were formaldehyde and acetaldehyde. Formaldehyde emissions were 
responsible for $53 \%$ and $67 \%$ of the measured carbonyl reactivity for LDVs and HDVs, respectively, compared with $47 \%$ and $33 \%$, respectively, for acetaldehyde emissions. These conclusions were also in accordance with the results of Brito et al. (2015), who showed that the use of ethanol led to an increase in acetaldehyde concentrations and a decrease in those of aromatics (e.g. benzene). Further studies are needed in order to characterise the evolution of VOC emissions in the atmosphere of the MASP, especially through long-term measurements at different sites.

\subsection{Particles}

Studies related to atmospheric aerosols in the MASP can be tracked back to early 1973. Because of their importance as a driver for climate studies and the relationship between PM concentrations and the burden of diseases, such studies focused on the composition and concentration of atmospheric aerosols. Some studies (e.g. Orsini and Boueres, 1977) sampled the mass size distribution variability with a sequential sampler and cascade impactor. The concentrations of inorganic material determined with X-ray fluorescence analysis showed the impact of the amount of sulfur (S) in the fuel and the presence of lead $(\mathrm{Pb})$ and bromine $(\mathrm{Br})$ due to the tetraethyl $\mathrm{Pb}$ added to the fuel as antiknocking agent (Figure 5). The concentration of $\mathrm{PM}_{2.5}$ was first measured in the $1980 \mathrm{~s}$ and was found to be approximately $30 \mu \mathrm{g} \mathrm{m}^{-3}$. Figure 5 illustrates the time variation of PM from the 1980s to the present. Although sample collection methods varied from year to year, most of the samples were collected on the main campus of the University of São Paulo, which is situated in the south-western zone of the city. The elemental concentration was obtained by X-ray fluorescence analysis performed with different equipment, starting with an alpha beam in a Pelletron accelerator (Orsini et al., 1984; Orsini and Boueres, 1977), a linear accelerator in Ghent (Andrade et al., 1994), a linear beam at the University of São Paulo Physics Institute (Andrade et al., 1993; Miranda et al., 2002), and more recently in a commercial X-ray fluorescence device (Miranda et al., 2012). The data were frequently used for multivariate analysis in order to identify the sources and their contributions to the concentration of PM.

The X-ray analysis showed good consistency among the years, with the expected decrease in $\mathrm{S}$ and $\mathrm{Pb}$ due to the air quality control policy implemented. In the 1980s, the concentration of $\mathrm{SO}_{2}$ often exceeded the air quality standards (Alonso et al., 1997) and the stationary sources have been controlled since then. At the end of the 1980s, the use 
of passenger cars began to increase (Carvalho et al., 2015). During the 1990s, the MASP experienced severe pollution problems and an increase in the concentration of particles. Although the PROCONVE, implemented in 1986, had imposed mandatory limits, regulations to control the emissions from trucks and buses were not put in place until the 1990s.

As shown in Figure 5, a significant decrease in the concentration of $\mathrm{Pb}$ resulted from the change from leaded gasoline to gasohol and from the use of pure ethanol as fuel. There was also a significant decrease in the concentrations of vanadium (V) and nickel (Ni) also showed a significant decrease, likely associated with the shift from the use of oilfired boilers to electrical boilers at industrial facilities. Another possible cause was the process of deindustrialisation of the city, during which some industries moved their operations to other cities in the state of São Paulo or even to other states. Those moves were prompted by the restrictions imposed on the installation of new, potentially polluting, industries in the MASP, which were motivated by the fact that the city was considered saturated for many air pollutants, according to CETESB regulations. Although some studies have attempted to correlate air pollution with changes in climate conditions in the MASP (Silva Dias et al., 2013), looking for relationships between rainfall and air pollution, no direct link has been found, because of the high impact of large-scale climatic conditions on local weather.

The elemental concentration has been considered for identification of pollutant sources in the MASP. The first studies applied factor analysis and absolute principal component analysis (e.g. Andrade et al., 1993; Castanho and Artaxo, 2001; Sánchez-Ccoyllo and Andrade, 2002). More recent studies have involved the use of positive matrix factorisation and its comparison with the results obtained with absolute principal component analysis. In all analyses, the main source is vehicular emissions, consistent with other studies (Andrade et al., 1994; Sánchez-Ccoyllo et al., 2007; Andrade et al., 2012). In an experiment performed in 2003, conducted in the downtown area of the MASP, vehicular emissions and industrial boilers continued to be the most important sources (Albuquerque, 2005).

Castanho and Artaxo (2001) found that OC accounted for $40 \%$ of $\mathrm{PM}_{2.5}$ in the MASP, and Ynoue and Andrade (2004) estimated that wintertime $\mathrm{PM}_{2.5}$ in the MASP consists 
of $34 \%$ OC, $9 \%$ EC, $19 \%$ crustal material, and $8 \%$ sulfate. For the coarse mode, the main source is the resuspension of urban dust, which is composed of crustal material from pavement abrasion. Hetem and Andrade (2016) analysed the composition of soil along roads and in road tunnels. The analysis showed the presence not only of crustal elements but also of black carbon and of metals that are enriched with crustal elements, such as $\mathrm{Cr}$ (chromium), V, Ni and Fe (iron).

In relation to the role of biofuel burning in the formation of fine particles, there have been a few studies conducted worldwide, including some which have indicated a decrease in particle emissions after an increase in the use of biofuels (e.g., Younga et al., 2012; Guarieiro et al., 2014). However, most such studies have been preliminary and have used chassis dynamometers to evaluate the role of biofuels. In the MASP, a recent decrease in the concentration of black carbon has been reported (Andrade et al., 2012). Monteiro dos Santos et al. (2016) presented concentrations of OC and EC measured at four sites in the MASP: in a street canyon, in the downtown area, in Ibirapuera Park and on the University of São Paulo (USP) campus. The authors found that the concentrations varied from 2.6 to $3.4 \mu \mathrm{g} \mathrm{m}^{-3}$ for OC and from 1.5 to $6.1 \mu \mathrm{g} \mathrm{m}^{-3}$ for EC, the reported concentrations being lowest for the Ibirapuera Park site and highest for the street canyon site. The EC concentrations found for the USP campus site were comparable to those reported in a previous study showing a decrease, although the concentrations were still high when compared with those found for the other sites. With the implementation of regulations for heavy duty vehicles, the concentrations of EC are expected to decrease. Tunnel studies have shown that emissions by the diesel fleet constitute the main source of organic aerosols in the MASP (Sanchez-Ccoyllo et al., 2009 and Brito et al., 2013). 


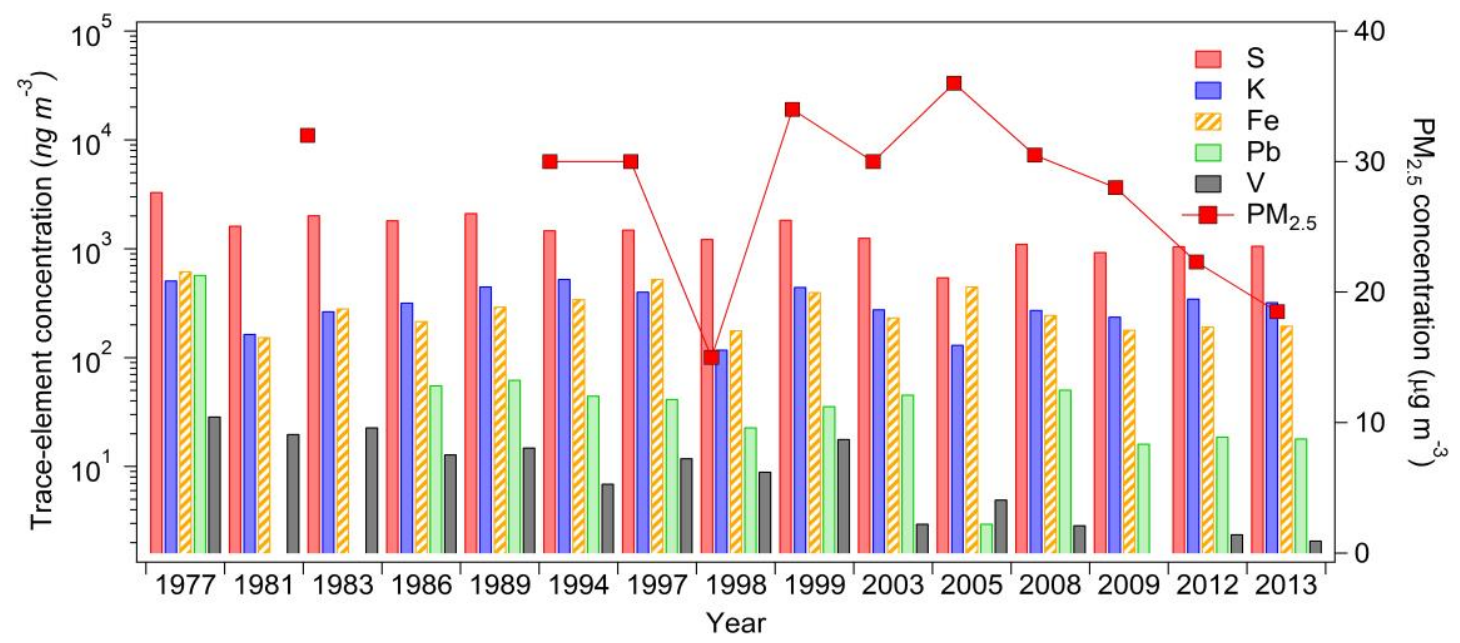

Figure 5: Mean annual concentrations of trace elements (in ng. $\mathrm{m}^{-3}$ ) present in the $\mathrm{PM}_{2.5}$ (in $\mu \mathrm{g} \cdot \mathrm{m}^{-3}$ ). The measurements were performed during different experimental campaigns and at different locations in the MASP: Data for 1977 are from Orsini and Boueres (1977); data for 1981 are from Orsini et al. (1984); data for the 1983-1986 period are from Andrade et al. (1994); data for 1994 are from Sánchez-Ccoyllo and Andrade (2002); data for 1997, 1998 and 1999 are from Miranda et al. (2012); data for 2003 are from Ynoue and Andrade (2004); data for 2005 are from Miranda et al. (2005); and data for the 2008-2012 period are from Oyama et al. (2015).

\subsection{Ultra Fine Particles (UFP)}

Particles below $100 \mathrm{~nm}$ in diameter (UFPs) are produced dominantly by the vehicular traffic (Kumar et al., 2011b, 2013b, 2014). Albuquerque et al. (2012) showed that primary pollutants, such as nitric oxide (NO), correlated with particles less than $50 \mathrm{~nm}$ and with particles between 50 to $100 \mathrm{~nm}$. The authors observed the occurrence of new particle formation as a result of the photochemical process (Figure 6). The high number of particles in the atmosphere over the MASP is related to vehicular emissions, as has been reported for other cities around the world (Kumar et al., 2010; Kumar et al., 2011a, 2013a, 2014), and the amount of black carbon in the lower stages of a cascade impactor has an impact on climate and adverse health effects.

Some studies concerning number distribution were performed in order to evaluate the emissions of nanoparticles and their hygroscopicity. Souto-Oliveira et al. (2016) showed that biomass burning events were related to higher values of activation diameter in Sao Paulo. 


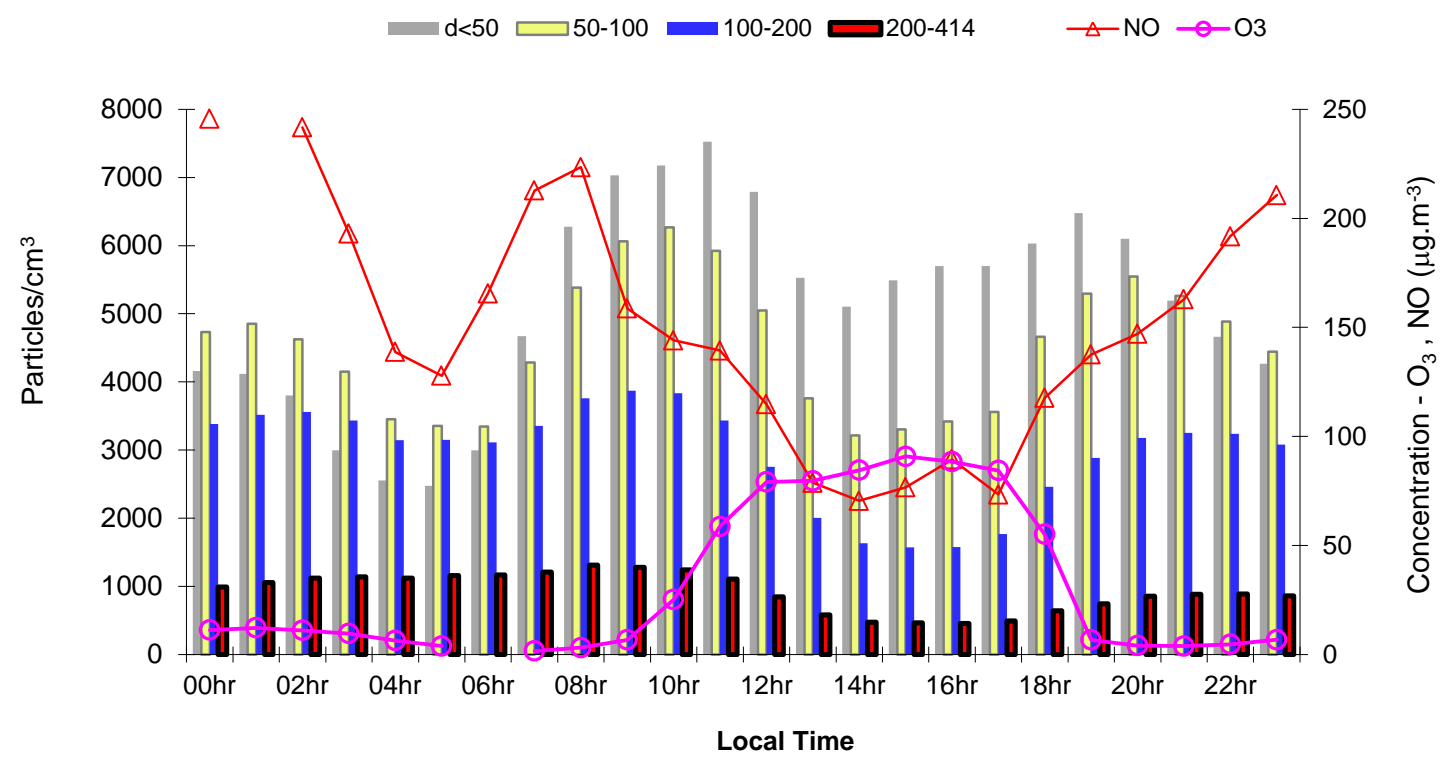

Figure 6: Hourly variation of nitric oxide (NO), ozone and particles at four different diameters (Albuquerque et al., 2012).

The authors also correlated the particle number concentrations with the number of cloud condensation nuclei and showed the role that primary emissions of inorganic and organic precursors play in the formation of nucleation bursts. However, the use of biodiesel has been shown to contribute to an increase in the UFP fraction (Martins et al., 2011), for several reasons: increased numbers of nucleation mode particles; reduced numbers of solid particles to promote production of new particles via nucleation and their growth to measurable sizes; and increased fuel mass flow rates to achieve the same power output.

Although the combustion of gasoline in vehicles can lead to higher UFP concentrations than does that of ethanol, some studies have shown that ethanol plays a role in secondary aerosol formation (Suarez-Bertoa et al., 2015). Emissions from diesel- and biodiesel-powered vehicles also have an influence on secondary UFP formation (Karavalakis et al., 2011; Hoekman et al., 2012; Rahman et al., 2014). There was a need for improvements in after-treatment technologies to reduce pollutant emissions, as could be the case for LDVs and HDVs in the MASP (the vehicles are currently newer and the situation has changed, even after increases in the use of ethanol and biodiesel in the fuel blends). Goel and Kumar (2015), evaluated the influence of nanoparticle emissions due to traffic conditions and the population exposure at traffic intersections. 


\section{Air quality modelling}

Air quality modelling in Brazil began at the end of the 1990s, when ozone concentrations over São Paulo were simulated by using offline models (Ulke and Andrade, 2001; Andrade et al., 2004; Sánchez-Ccoyllo et al., 2006a, Vivanco and Andrade, 2006; Sánchez-Ccoyllo et al., 2007; Martins and Andrade, 2008b). At that time, the way that turbulence was treated in the models was a major concern, because the models used were very simple in order to make it possible to perform integrations with the computers that were available, which were slow and lacked sufficient memory, both for integration and for data storage. As offline models do not allow an appropriate representation of meteorological fields, the influence of atmospheric conditions on air quality used to be performed by using other numerical models or results from global analyses, as in the studies conducted by Sánchez-Ccoyllo and Andrade (2002) and Sánchez-Ccoyllo et al. (2006b).

Despite the limitations of the models applied in the abovementioned studies, the study conducted by Martins and Andrade (2008a) made a major contribution. The authors evaluated a set of different numerical scenarios, some of them involving reductions in the concentrations of species that are associated with higher ozone sensitivity, one specific scenario considering hydrated ethanol as the principal fuel. The results suggest that both situations-improvement in the quality of Brazilian gasohol (reductions in chemical species such as olefins and aromatics such as benzene) and an increase in the participation of ethanol-could produce a reduction in the ozone concentration. However, if the fuel considered were gasohol of good quality (California standards in the first years of the new millennium), ozone concentrations in the MASP could be increased by flex-fuel cars shifting from gasohol to ethanol.

With the development of powerful computer systems, the simulation of chemical reactions inside mesoscale models, the so-called inline or online models, was made possible. In Brazil, two different mesoscale models were applied with the purpose of forecasting not only the atmospheric behaviour but also air quality. The first of those models was the Regional Atmospheric Modelling System (RAMS, Pielke et al., 1992; Cotton et al., 2003) that was coupled with a Simple Photochemical Module, described in Freitas et al. (2005), and a physically-consistent treatment for urban areas, the Town Energy Budget, based on the work of Masson (2000), as described in Rozoff et al. (2003) and Freitas et al. (2007). These two parameterisations were also coupled to the Brazilian RAMS, which is called BRAMS (Freitas et al., 2009; Longo et al., 2010; 
Freitas et al., 2017). Many studies have been made by using the BRAMS since then. Vendrasco et al. (2009) applied the BRAMS to study the effects of biomass burning aerosols on precipitation over the Amazon region. They found that the influence of aerosols can cause precipitation to increase, because of dynamic forcing on pressure gradients, or to decrease, because of radiative forcing, depending on the aerosol loading into the atmosphere. Freitas et al. (2009) described a major development of the model for representing biomass burning and related processes that culminate in the transport of aerosols and gases far from their sources. The coupled aerosol and tracer transport BRAMS is largely used in the operational air quality forecast at the Centre for Weather Forecasting and Climate Studies of the Brazilian National Institute for Space Research, the latest version having been made available on the website (http://brams.cptec.inpe.br/) and fully described in Freitas et al. (2017).

Another model that is being widely used in Brazil is the Weather Research and Forecast with Chemistry (WRF/Chem) model, described in Grell et al. (2005). For example, Wu et al. (2011) evaluated the performance of the WRF/Chem model during the dry season in South America, including its representation of aerosol, clouds, precipitation and chemistry. Although the authors found problems in the cumulus and microphysical parameterisations in representing water vapor in the upper troposphere, the spatial distribution of biomass burning aerosols was well represented by the model.

The WRF/Chem model is being employed for air quality forecasting in south-eastern Brazil (Andrade et al., 2015), because it describes the formation of secondary organic aerosol and ozone, which present a challenge not only for their control but also for understanding their formation processes. The comparison between simulated and measured concentrations has shown good statistical indices for the MASP. Vara-Vela et al. (2016) used the WRF/Chem model to study how vehicular emissions can affect fine particle formation and showed that approximately $30 \%$ of secondary particle production in the MASP is due to primary gases emitted mostly by vehicles.

\subsection{Emissions modelling}

Vehicular emissions are the main source of precursors for ozone and secondary aerosol in the MASP. The CETESB provides a yearly official mobile inventory for the MASP for $\mathrm{CO}, \mathrm{NO}_{x}, \mathrm{SO}_{x}, \mathrm{VOCs}$ and $\mathrm{PM}_{10}$. The vehicle types consist of motorcycles, LDVs and HDVs with emissions from the following process: exhaust, evaporative and 
refuelling and crankcase. Vehicular emissions decreased from 1990 to 2015: from 1,308 $k$ ton to $163 k$ ton for CO, from $207 k$ ton to $40 k$ ton for VOCs, from $200 k$ ton to $55 k$ ton for $\mathrm{NO}_{x}$, from $21 k$ ton to $1.5 k$ ton for $\mathrm{PM}_{10}$ and from $78 k$ ton to $1.5 k$ ton for $\mathrm{SO}_{x}$. The greatest challenges for emission modelling in the 1990s were to distribute the emissions of pollutants spatially and temporally and to allocate the total VOCs into the chemical compound classes based on the Atmospheric Chemical Mechanisms and VOC Reactivity Scales mechanism used at that time (Andrade et al., 2004). Emission factors were taken from the literature, where there is little information concerning the combustion of fuels such as ethanol and gasohol. Several ambient and tunnel measurement campaigns took place from the early 2000s to 2011 (Martins et al., 2006; Perez-Martinez et al., 2014; Nogueira et al., 2015b). These studies provided real vehicular emission factors, which were continuously incorporated into the emission models.

There is a lack of knowledge regarding the contributions of the emission sources and their temporal and spatial variability. To overcome this problem, different methods were applied, including the use of nocturnal satellite data (Martins et al., 2013), the International Emission Database emission inventory (Vara-Vela et al., 2016) and more recently the Mobile Emissions Scheme, developed by Ibarra et al. (2016, submitted). However, there is still a lack of adequate information for fixed sources to be used for air quality modelling. Surrounding the MASP, there are major industrial centres (in the regions of the cities of Campinas, Cubatão, Sorocaba and São José dos Campos) and thermal power plants burning sugarcane bagasse, all of which can influence the atmospheric chemistry of the state of São Paulo. Kawashima et al. (2015) prepared an emission inventory of pollutants emitted from power thermal plants burning sugarcane bagasse in Brazil, and PM proved to be the most representative pollutant emitted by this sector.

The newest version of the Mobile Emissions Scheme (Ibarra et al., 2016, submitted) consists of a bottom-up approach, using vehicular counts on different types of roads and emissions for several pollutants for each road in the MASP on an hourly basis. Those emissions will be used as input for air quality modelling. 


\section{Exposure and health}

Heavy air pollution conditions in the MASP have been reported, which has serious effects on human health. According to Bravo et al. (2016), more than 99,000 deaths are attributed to air pollution every year. In a modelling analysis, Miranda et al. (2012) showed that nearly 10,000 deaths per year are associated with $\mathrm{PM}_{2.5}$. The population segments at the greatest risk are the elderly and children. For example, Saldiva et al. (1994) found a significant association between childhood mortality due to respiratory diseases and $\mathrm{NO}_{x}$ levels. Foetal mortality in the MASP has been shown to correlate strongly with the $\mathrm{NO}_{2}$ concentration, as well as (to a lesser degree) with the concentrations of $\mathrm{SO}_{2}$ and $\mathrm{CO}$ (Pereira et al., 1998). Lin et al. (1999) estimated an increase of $20 \%$ in emergency room visits by children for respiratory diseases on the most polluted days in the MASP. In addition, Braga et al. (1999) found that the mean levels of $\mathrm{PM}_{10}$ were associated with a $12 \%$ increase in the incidence of respiratory diseases among children under 13 years of age. Conceição et al. (2001) also found that childhood deaths from respiratory diseases correlate positively with the concentrations of $\mathrm{CO}, \mathrm{SO}_{2}$ and $\mathrm{PM}_{10}$. Other studies conducted in the MASP have found associations between increased admissions for respiratory diseases in children and the concentrations of air pollutants such as $\mathrm{PM}_{10}, \mathrm{CO}, \mathrm{SO}_{2}$ and ozone (Gouveia and Fletcher, 2000; Freitas et al., 2004). The $\mathrm{SO}_{2}$ concentration is also associated with neonatal deaths, as is that of $\mathrm{PM}_{10}$ (Lin et al., 2004). Ribeiro and Cardoso (2003) showed that the control of a single pollutant was insufficient to protect child health and that political control should be reinforced in order to yield health benefits in the MASP. Synoptic events can also affect air pollutant concentrations and as a consequence wheezing in children, as shown in Mendez et al. (2014). Ozone is also directly associated with diabetes and cardiovascular diseases, as shown in Pereira Filho et al. (2008). The elderly are greatly affected by the damaging effects of air pollution. In a study conducted by Saldiva et al. (1995), the correlation between pollution and mortality in individuals $\geq 65$ years of age was most significant for $\mathrm{PM}_{10}$, the dose-response relationship being nearly linear with no evidence of a safe threshold level. In the MASP, an increase of $10 \mu \mathrm{g} \mathrm{m}^{-3}$ in $\mathrm{SO}_{2}$ corresponds to an increase of $3.4 \%$ in the number of deaths from myocardial infarction (Sharovsky et al., 2004). Gonçalves et al. (2007) presented similar results, in which the determination of the impacts of $\mathrm{PM}_{10}$ and $\mathrm{SO}_{2}$, as well as thermal comfort indices, were found to be the best tools for comparing weather and pollutants with cardiovascular mortality and morbidity in the MASP. In addition, $\mathrm{PM}_{10}$ and $\mathrm{SO}_{2}$ have been shown to 
have acute effects on chronic obstructive pulmonary disease-related morbidity, whereas $\mathrm{CO}$ and $\mathrm{NO}_{2}$ have been shown to have slight deleterious effects on health in the elderly (Arbex et al., 2009). A 10-year analysis in the MASP showed that an increase of $10 \mu \mathrm{g}$ $\mathrm{m}^{-3}$ in the concentration of $\mathrm{PM}_{10}$ causes an increase in the relative risk of death from respiratory diseases in the elderly (Pinheiro et al., 2014). Recently, Segalin et al. (2016) characterised the mass of size-segregated PM in elderly residences in the MASP and found, for example, that the indoor concentrations of $\mathrm{PM}_{2.5}$ and $\mathrm{PM}_{10}$ were higher than the outdoor concentrations in approximately $77 \%$ and $40 \%$, respectively, of those residences.

The health effect of exposure to air pollution is dependent on the dose-response relationship, and the exposure time and concentrations are therefore crucial. For example, Braga et al. (2001) found that adolescents (individuals over 13 years of age) appeared to be one of the groups that are most susceptible to air pollution in the MASP, second only to children 0-2 years of age, because they are more exposed to outdoor air pollution than are children between 3 and 13 years of age. In addition, the associations are significant within a time lag of 1-7 days and are dose-dependent. Many studies concerning air pollution and health effects, especially for elderly people and children (children being more susceptible), have been conducted in the MASP. However, there have been few studies evaluating the size and chemical composition of particles and their health effects. Therefore, some scientific gaps remain. For example, what are the main chemical elements and particle size ranges responsible for respiratory diseases in children and elderly in the MASP? What is the intake doses of particles received by a person living in São Paulo considering outdoor and indoor environments? Martins et al. (2010) studied the UFP number distributions in the MASP under clean and polluted periods, and they found that the total UFP number did not differ significantly between the periods, even with more significant effects of particle deposition on human respiratory health under clean atmospheric conditions), because the geometric mean diameter was larger under polluted conditions than under clean conditions. Oliveira et al. (2011) conducted a systematic review considering the physical and chemical characteristics of pollutants and their health effects in Brazil. However, further studies concerning the real indoor and outdoor exposure and health effects are needed, even in medium-sized cities. 


\section{Climate change and its impact on air quality, human activities and public health}

The climate in the MASP is subtropical, with mild temperatures, warm, humid summers (December through February) and cool, dry winters (June through August). The annual average, minimum, and maximum temperatures in the city of São Paulo were $19.2{ }^{\circ} \mathrm{C}$, $15.5^{\circ} \mathrm{C}$ and $24.9^{\circ} \mathrm{C}$ during the $1961-1990$ period (INMET, 2016). Temperatures in MASP, however, may drop near $0^{\circ} \mathrm{C}$ in winter and rise above $30^{\circ} \mathrm{C}$ in summer, depending on the occurrence of meteorological phenomena at various scales, including frontal systems, sea breezes and the urban heat island effect. The distribution of rainfall is also influenced by weather systems such as cold fronts, the South Atlantic Convergence Zone, squall lines and sea breezes.

Brazil has experienced climate changes since the 1950s. Such climate changes have included increased air temperature, wind speed, and atmospheric stability, as well as reduced precipitation, relative humidity, and cloud cover (e.g. Ackerman et al., 2000; Kaufman et al., 2002; Hoffman et al., 2003; Oyama and Nobre, 2003; Koren et al., 2004; Andreae et al., 2004; Costa et al., 2007; Sampaio et al., 2007). As a consequence of climate change, extreme weather events have become more intense and frequent in south-eastern South America (Marengo, 2009). Examples of these events include several heat waves in 2004 in the MASP $\left(>32.1^{\circ} \mathrm{C}\right)$ and in Rio de Janeiro (Nobre et al., 2010) and in most of Brazil (> 40 ${ }^{\circ}$ ) in 2014 (Alves et al., 2016), as well as severe drought events in Brazil in 1998, 2005 and 2010 (Nepstad et al., 2004; Aragão et al., 2007; Marengo et al., 2016).

The heat wave in Brazil in January and February of 2014 increased energy consumption due to increased demand for residential air conditioning (MME, 2014a, b). Such an increase has sequential impacts on the climate, air quality, ecosystem, economy and human health. For example, the rising atmospheric $\mathrm{CO}_{2}$ concentrations resulting from increased carbon emissions will in turn accelerate the rate of anthropogenic global warming. Extreme flood and drought events can cause not only economic and ecological damage but also the loss of lives.

A number of studies have projected climate changes under various scenarios in Brazil using general circulation models and dynamical downscaling methods with regional 
climate models (e.g. Grimm and Natori, 2006; Vera et al., 2006; IPCC, 2007; Baettig et al., 2007; Bombardi and Carvalho 2009; Marengo et al., 2009, 2010a, b; Rusticucci et al. 2010; Llopart et al., 2014). For example, Nobre et al. (2010) projected an increase in the number of hot days and warm nights, as well as a reduction in the number of cold days and cold nights, in the MASP. Considering an urban growth scenario to analyse the urban expansion from 2008 to 2030, Young (2013) found that the area will increase by $38 \%$, with a simultaneous increase in the flood risk zones.

In addition to the disruption of future natural systems, climate change will have a variety of impacts on future human activities, health and migration, as well as on various sectors, such as agriculture, industry, food production, forestry and tourism. The examples of health impacts may include increased mortality and morbidity due to climate extremes and associated air/water/soil pollution, increased outdoor and indoor discomfort conditions for human activities, an increase in infectious diseases associated with water scarcity (e.g. diarrhoea), poor nutrition, and a hot, dry climate (e.g. dehydration, respiratory diseases and dengue fever), as well as regional redistribution of endemic diseases due to the migration of populations from rural areas to the large cities and from arid/drought regions to non-drought regions. Several studies have examined the impacts, in Brazil in general and in the MASP, of climate change on public health (Confalonieri et al., 2009); agriculture and industry (Oliver et al., 2012); tourism (Jenkins and Nicholls, 2010); maritime navigation (Pezzoli et al., 2013); and residential conditions (Alves et al., 2016). For example, Confalonieri et al. (2009) applied an "exposure-response" model to study vulnerability of the Brazilian population to the health impacts of climate change. They found that the north-eastern region is the most vulnerable region in terms of the possible impacts of climate change on tropical infectious diseases, resulting from a combination of poor socio-economic indicators, a semi-arid climate prone to extreme variations and the persistence of major endemic infectious diseases such as malaria, dengue fever and leptospirosis in this region. Alves et al. (2016) studied indoor thermal performance and comfort for the elderly in the MASP and reported an increase in heat sensation and a decrease in cold sensation in comfort conditions under the climate scenarios, which, in conjunction with climate change and heat waves, may lead to heat discomfort. Batista et al. (2016) studied the effect of projected climate change on the thermal comfort index, the indoor perceived equivalent temperature (IPET), over the MASP under the representative concentration 
pathway 8.5 scenario. They reported a warming pattern for IPET, which increased from $19.1-21.3^{\circ} \mathrm{C}$ during the $1975-2005$ period to $23.5-25.1^{\circ} \mathrm{C}$ for the projected period (2065-2099). Such increases in IPET could affect many aspects of human life and even the entire society of the MASP. A few studies have examined the benefits of climate mitigation strategies. For example, Cifuentes et al. (2001) studied the potential local health benefits of adopting greenhouse gas mitigation policies in four megacities: Mexico City; Santiago (Chile); São Paulo; and New York City. The authors reported that, among those four cities, São Paulo would have the second highest avoided mortality (a total of 12,481 annual deaths currently being caused by $\mathrm{PM}_{10}$ and ozone exposure) resulting from greenhouse gas emission controls. However, there have been a limited number of studies that have reported health impacts related to the direct effects of climate extremes (e.g. storms, floods and drought), because of the lack of a reliable national database on morbidity and mortality related to these events in Brazil. To address this knowledge gap, a new program, a Platform for Understanding Long-term Sustainability of Ecosystems and Human Health (referred to as PULSE-Brazil, http://www.pulse-brasil.org/tool/) has recently been established to examine the impacts of climate extremes on ecosystems and human health in Brazil (Marengo et al., 2016). In a recent study sponsored by the US National Institutes of Health, mortality in São Paulo was found to be associated with cold and heat waves during the 1996-2010 period and certain subpopulations, such as the elderly, were found to be more vulnerable than is the general public (Son et al., 2016).

\section{Summary, conclusions and future outlook}

Many successful programs implemented by governmental agencies, following international initiatives, have been reducing the emission of primary pollutants by stationary and mobile sources in the MASP. Although these programs for monitoring industrial and vehicular sources were highly successful in reducing the emissions of primary atmospheric pollutants such as $\mathrm{CO}, \mathrm{NO}_{x}, \mathrm{SO}_{2}$ and $\mathrm{PM}_{10}$, those of secondary pollutants, such as ozone and fine particles, have yet to be controlled. Carvalho et al. (2015) reported the values of annual mean tendency of the concentrations of all pollutants monitored by CETESB from 1996 to 2009. The authors showed a clear decrease in the pollutants monitored, except for $\mathrm{O}_{3}$. Annual mean concentration levels 
decrease for $\mathrm{CO}$ (10 of 10 stations), $\mathrm{NO}_{x}$ (7 of 8 stations), $\mathrm{PM}_{10}$ (20 of 20 stations), $\mathrm{SO}_{2}$ (5 of 5 stations) and $\mathrm{O}_{3}$ (6 of 11 stations).

Many efforts have been made to quantify the role of VOCs in ozone formation, based on the specific attributes of the biofuels used in the MASP. However, the results have shown that, despite the use of biofuels, ozone concentrations have not decreased; on the contrary, such concentrations have shown a slight increase over time.

On the basis of this review, we can make some recommendations to improve the air quality in the MASP, which can also be applied to other urban areas in South America. The impacts of emissions by some sources have not been properly evaluated, such sources including evaporative emissions, in the refuelling process at gas stations as well as running losses, and the use of wood and charcoal for cooking in restaurants and elsewhere. As the big challenge in many urban areas in the world is the transportation sector, which is responsible for most of the emissions and impairs quality of life, in terms of accessibility and loss of time, impacting the most vulnerable population (residents of the periphery). Initiatives to improve public transportation, by using cleaner fuels and applying new technologies to reduce noise and travel time, will improve quality of life. Despite the fact that half of all emissions of $\mathrm{CO}, \mathrm{HC}$ and $\mathrm{NO}_{x}$ in the MASP are from vehicles that are more than 10 years old, the scrapping of old vehicles is not obligatory in the city (with the exception of city buses, which are taken off the road after 5 years). In this context, the obvious step would be to scrap old vehicles (those 10-15 years of age), which would be in line with the established practices in most megacities. As for air quality standards, the implementation of the WHO guidelines would enforce more restrictive standards for pollutant emissions.

Although the use of air quality modelling combined with observed (measured) values has proved to be a powerful tool in the description of the dynamics of photochemical formation of pollutants, there is still room for improvement in the emission inventories. The lack of information concerning stationary sources and evaporative emissions is an important barrier to describing the formation of secondary pollutants in the MASP.

Although climate changes in the MASP have been studied extensively, there have been a limited number of studies on the impact of such changes, climate extremes in particular, on air quality and human health, which warrants further research. Fewer studies have been performed to understand the chemistry-climate interactions in Brazil, particularly the feedbacks of air pollutants, such as atmospheric aerosol, to the climate system. 


\section{Acknowledgements}

PK, MFA, YZ, RY and EF thank the University Grant Partnership Network (UGPN) funded projects, BIOBURN (Towards the Treatment of Aerosol Emissions from Biomass Burning in Chemical Transport Models through a case study in the Metropolitan Area of São Paulo) and NEST-SEAS (Next-Generation Environmental Sensing for Local To Global Scale Health Impact Assessment) for the funding provided for this work. PK and MFA also acknowledge the support from FAPESP-ESRC-NWO funded project ASTRID (Accessibility, Social justice and TRansport emission Impacts of transit-oriented Development strategies; ES/N011481/1) for this collaborative effort.

The LAPAt group acknowledges the FAPESP-funded project NUANCE (Narrowing the Uncertainties in Aerosol and Climate Change; Grant number 2008/58104-8). TN acknowledges FAPESP and CNPq for providing Fellowship Grant nos. 2011/18777-6 and 165781/2015-7. LD also acknowledges the support from CNPq (Process nos. 404104/2013-4 and 303491/2015-9). YZ also acknowledges the support from the National Science Foundation EaSM program (AGS-1049200) at NCSU.

\section{References}

Ackerman, A. S., Toon, O. B., Stevens, D. E., Heymsfield, A. J., Ramanathan, V., Welton, E. J., 2000. Reduction of tropical cloudiness by soot. Science, 288, 1042 1047, doi:10.1126/science.288.5468.1042.

Allen, A. G., McGonigle, A. J. S., Cardoso, A. A., Machado, C. M. D., Davison, B., Paterlini, W. C., Rocha, G. O., Andrade, J. B., 2009. Influence of sources and meteorology on surface concentrations of gases and aerosols in a coastal industrial complex. Journal of the Brazilian Chemical Society 20, 214-221. http://dx.doi.org/10.1590/S0103-50532009000200004

Albuquerque, T. T. A. Distribuições de Tamanho, Composição Química e Identificação das Fontes do Aerossol Atmosférico de São Paulo: Um Estudo de Caso Para o Inverno de 2003. 2005. 120 f. Dissertação (Mestrado em Meteorologia) Universidade de São Paulo.

Albuquerque, T. T. A.; Andrade, M. F., Ynoue, R. Y., 2012. Characterization of atmospheric aerosols in the city of São Paulo, Brazil: comparisons between polluted and unpolluted periods. Environmental Monitoring and Assessment, 184 (2), 969 - 984, doi:10.1007/s10661-011-2013-y. 
Alonso, C. D., Martins, M. H. R. B., Romano, J., Godinho R., 1997. São Paulo Aerosol Characterization Study. Journal of the Air and Waste Management Association, 47, 1297-1300. http://dx.doi.org/10.1080/10473289.1997.10464070.

Alves, C. A., Duarte, D. H. S., and Goncalves, F. L. T., 2016. Residential buildings' thermal performance and comfort for the elderly under climate changes context in the city of Sao Paulo, Brazil. Energy and Buildings, 114, 62-71, http://dx.doi.org/10.1016/j.enbuild.2015.06.044.

Andrade, M. F., Orsini, C., Maenhaut, W., 1993. Receptor Modeling for Inhalable Atmospheric Particles in São Paulo, Brazil. Nuclear Instruments and Methods in Physics Research, Section B: Beam Interactions with Materials and Atoms. 75(1-4), 308-311, doi:10.1016/0168-583X(93)95665-R.

Andrade, M. F., Orsini, C., Maenhaut, W., 1994. Relation between aerosol sources and meteorological parameters for inhalable atmospheric particles in São Paulo city, Brazil. Atmospheric Environment, 28 (14), 2307-2315, doi:10.1016/13522310(94)90484-7.

Andrade, M. F., Ynoue, R. Y, Harley, R., Miguel, A. H., 2004. Air-Quality Model simulating photochemical formation of pollutants: the São Paulo Metropolitan Area, Brazil. International Journal of Environment and Pollution, 22, $460-475$, http://dx.doi.org/10.1504/IJEP.2004.005681.

Andrade, M. F., Miranda, R. M., Fornaro, A., Kerr, A., Oyama, B., André, P. A., Saldiva, P. H., 2012. Vehicle emissions and PM2.5 mass concentrations in six Brazilian cities. Air Quality, Atmosphere, \& Health, 5 (1), 79-88, doi: 10.1007/s11869-010-0104-5.

Andrade, M. F., Ynoue, R. Y, Freitas, E. D., Todesco, E., Vara Vela, A., Ibarra, S., Martins, L. D., Martins, J. A., Carvalho, V. S. B., 2015. Air quality forecasting system for Southeastern Brazil. Frontiers in Environmental Science, 3, 1-14, doi: http://dx.doi.org/10.3389/fenvs.2015.00009.

Andreae, M. O., Rosenfeld, D., Artaxo, P., Costa, A. A., Frank, G. P., Longo, K. M., Silva Dias, M. A. F., 2004. Smoking rain clouds over Amazonia, Science, 303, 1337-1342, doi:10.1126/science.1092779.

ANP, 2016. Petroleum, Natural Gas, and Biofuels National Agency, Brazil. http://www.anp.gov.br. (accessed 20.07.2016). 
Aragão, L. E. O. C., Malhi, Y., Roman-Cuesta, R. M., Saatchi, S. Anderson, L. O., Shimabukuro, Y. E., 2007. Spatial patterns and fire response of recent Amazonian droughts, Geophysical Research Letters, 34, L07701, doi:10.1029/2006GL028946.

Arbex, M. A., Souza Conceição, G. M., Cendon, S. P., Arbex, F. F., Lopes, A. C., Moysés, E. P., Santiago, S. L., Saldiva, P. H. N., Pereira, L. A. A., Braga, A. L. F., 2009. Urban air pollution and chronic obstructive pulmonary disease-related emergency department visits. Journal of Epidemiology \& Community Health 63, 777-783, doi: 10.1136/jech.2008.078360.

Atkinson, R., 2000. Atmospheric chemistry of VOCs and NOx. Atmospheric Environment, 34, 2063-2101. http://dx.doi.org/10.1016/S1352-2310(99)00460-4.

Baettig, M. B., Wild, M., Imboden, D.M., 2007. A climate change index: Where climate change may be most prominent in the 21 st century, Geophysical Research Letters, 34, L01705, doi:10.1029/2006GL028159.

Batista, R., F. L. T. Gonçalves; R. P. da Rocha, 2016. Present climate and future projections of the thermal comfort index for the metropolitan region of São Paulo, Brazil. Climate Change, 137 (3), 439-454. doi:10.1007/s10584-016-1690-5.

Boian, C., Andrade, M. F., 2012. Characterization of ozone transport among Metropolitan Regions. Revista Brasileira de Meteorologia 27(2), 229-242. http://dx.doi.org/10.1590/S0102-77862012000200009.

Bombardi R. J., Carvalho L. M. V., 2009. IPCC Global coupled climate model simulations of the South America Monsoon System. Climate Dynamics, 33, 893916, doi:10.1007/s00382-008-0488-1.

Braga, A. L. F., Conceição, G. M. S., Pereira L. A. A., Kishi, H.S., Pereira, J. C. R., Andrade, M. F., Gonçalves F. L. T., Saldiva, P. H. N., 1999. Air pollution and pediatric respiratory hospital admissions in S. Paulo, Brazil. Journal of Environmental Medicine, 1 (2), 95-102, doi: 10.1002/(SICI)10991301(199904/06)1:2<95::AID-JEM16>3.0.CO;2-S

Braga, A. L. F., Saldiva, P. H. N., Pereira, L. A. A., Menezes, J. J. C., Conceição, G. M. S., Lin, C. A., Zanobetti, A., Schwartz, J., Dockery, D., 2001. Health Effects of air pollution exposure on children and adolescents in São Paulo, Brazil. Pediatric Pulmonology 31 (2), 106-113, doi: 10.1002/1099-0496(200102)31:2<106::AIDPPUL1017>3.0.CO;2-M.

Bravo, M.A., Son, J., de Freitas, C.U., Gouveia, N., Bell, M.L., 2016. Air pollution and mortality in São Paulo, Brazil: Effects of multiple pollutants and analysis of 
susceptible populations. Journal of Exposure Science \& Environmental Epidemiology, 26(2), 150-161, doi:10.1038/jes.2014.90.

Brito, J., Rizzo, L. V., Herckes, P., Vasconcellos, P. C., Caumo, S. E. S., Fornaro, A., Ynoue, R. Y., Artaxo, P., and Andrade, M. F., 2013. Physical-chemical characterisation of the particulate mat- ter inside two road tunnels in the São Paulo Metropolitan Area, Atmos. Chem. Phys., 13, 12199-12213, doi:10.5194/acp-1312199-2013.

Brito, J., Wurm, F., Yanez-Serrano, A.M., Assunção, J.V., Godoy, J.M., Artaxo, P., 2015. Vehicular Emission Ratios of VOCs in a Megacity Impacted by Extensive Ethanol Use: Results of ambient measurements in São Paulo, Brazil. Environ. Sci. Technol., 49 (19), 11381-11387, doi:10.1021/acs.est.5b03281.

Caderno Metropole/Observatorio das Metropoles (2013). Mobilidade Urbana nas metropoles contemporaneas. Vol. 15, n 30, 363-670.

Carvalho, V. S. B., Freitas, E. D., Martins, L. D., Martins, J. A., Mazzoli, C. R., Andrade, M. F., 2015. Air quality status and trends over the Metropolitan Area of São Paulo, Brazil as a result of emission control policies. Environmental Science \& Policy, 47, 68-79, doi:10.1016/j.envsci.2014.11.001.

Castanho, A. D. A.; Artaxo, P. E., 2001. São Paulo Aerosol Source Apportionment for Wintertime and Summertime. Atmospheric Environment, v. 35, p. 4889-4902, http://dx.doi.org/10.1016/S1352-2310(01)00357-0.

CETESB, 2004, Relatório de Qualidade do Ar no Estado de São Paulo 2003, Série Relatórios, São Paulo, CETESB, 137 p. http://ar.cetesb.sp.gov.br/publicacoesrelatorios.(accessed 04.09.2016).

CETESB, 2014. Companhia Ambiental do Estado de São Paulo. Qualidade do ar no estado de São Paulo 2013, 110 p. http://ar.cetesb.sp.gov.br/publicacoes-relatorios/ (accessed 04.09.2016).

CETESB, 2015. Companhia Ambiental do Estado de São Paulo. Qualidade do ar no estado de São Paulo 2014. http://ar.cetesb.sp.gov.br/publicacoes-relatorios/ (accessed 02.03.2016).

CETESB, 2016. Companhia de Tecnologia de Saneamento Ambiental, 2015. Relatório de qualidade do ar no Estado de São Paulo 2015, Report of air quality in the São Paulo State 2015. Cetesb, São Paulo. Available at http://ar.cetesb.sp.gov.br/publicacoes-relatorios/ (accessed 02.03.2016). 
IPCC, 2007: Climate Change 2007: The Physical Science Basis. Contribution of Working Group I to the Fourth Assessment Report of the Intergovernmental Panel on Climate Change [Solomon, S., D. Qin, M. Manning, Z. Chen, M. Marquis, K.B. Averyt, M. Tignor and H.L. Miller (eds.)]. Cambridge University Press, Cambridge, United Kingdom and New York, NY, USA, 996 pp.

Cifuentes, L., Borja-aburto, V. H., Gouveia, N., Thurston, G., Davis, D. L., 2001. Assessing the Health Benefits of Urban Air Pollution Reductions Associated with Climate Change Mitigation (2000 - 2020 ): Santiago, São Paulo, México City, and New York City. Environmental Health Perspectives, 109(Suppl 3), 419-425, doi: $10.2307 / 3434790$

City Population, 2016. Population statistics for countries, administrative areas, cities and agglomerations. http://www.citypopulation.de/world/Agglomerations.html (accessed 24.02.2016).

Conceição, G. M. S., Miraglia, S. G. E. K., Kishi, H. S., Saldiva, P. H. N., Singer, J. M., 2001. Air pollution and child mortality: A time-series study in São Paulo, Brazil. Environmental Health Perspectives, 109 (Suppl 3), 347-350, doi: 10.2307/3434781.

Confalonieri, U. E. C., Marinho, D. P., Rodriguez, R. E., 2009. Public health vulnerability to climate change in Brazil, Climate Research, 40, 175-186, doi:10.3354/cr00808.

Costa, M. H., Yanagi, S. N. M., Souza, P. J. O. P., Ribeiro, A., Rocha, E. J. P., 2007. Climate change in Amazonia caused by soybean cropland expansion, as compared to caused by pastureland expansion, Geophysical Research Letters, 34, L07706, doi:10.1029/2007GL029271.

Cotton, W. R., Pielke, R. A., Walko, R. L., Liston, G. E., Tremback, C. J., Jiang, H., McAnelly, R. L., Harrington, J. Y., Nicholls, M. E., Carrio, G. G., McFadden, J. P., 2003. RAMS 2001: Current status and future directions. Meteorology and Atmospheric Physics 82, 5-29. DOI:10.1007/s00703-001-0584-9.

DENATRAN, 2015. National Department of Traffic Road. http://www.denatran.gov.br/frota2015.htm (accessed on 04.02.2016).

Dominutti, P.A, Nogueira, T., Borbon, A., Andade, M. F., Fornaro, A., 2016. One-year of NMHCs hourly observations in Sao Paulo megacity: meteorological and traffic emissions effects in a large ethanol burning context. Atmospheric Environment 142, 371-382, http://dx.doi.org/10.1016/j.atmosenv.2016.08.008. 
Freitas, C., Bremner, S. A., Gouveia, N., Pereira, L. A. A., Saldiva, P. H. N., 2004. Hospital admissions and mortality: association with air pollution in São Paulo, Brazil, 1993 to 1997. Revista de Saúde Pública, 38(6), 751-757, http://dx.doi.org/10.1590/S0034-89102004000600001.

Freitas, E. D., Martins, L. D., Silva Dias, P. L., Andrade, M. F., 2005. A Simple Photochemical Module Implemented in RAMS for Tropospheric Ozone Concentration Forecast in the Metropolitan Area of Sao Paulo - Brazil: Coupling and Validation. Atmospheric Environment, v. 39, n.34, p. 6352-6361, http://dx.doi.org/10.1016/j.atmosenv.2005.07.017.

Freitas, E. D., Rozoff, C. M., Cotton, W. R, Silva Dias, P. P., 2007. Interactions of an urban heat island and sea-breeze circulations during winter over the metropolitan area of Sao Paulo, Brazil, Boundary-Layer Meteorology, 122(1), 43-65, doi:10.1007/s10546-006-9091-3.

Freitas, S. R., Longo, K. M., Silva Dias, M. A. F., Chatfield, R., Silva Dias, P., Artaxo, P., Andreae, M. O., Grell, G., Rodrigues, L. F., Fazenda, A., Panetta, J., 2009. The coupled aerosol and tracer transport model to the Brazilian developments on the regional atmospheric modeling system (CATT-BRAMS) Part 1: model description and evaluation, Atmospheric Chemistry and Physics, 9, 2843-2861, doi:10.5194/acp-9-2843-2009.

Freitas, S. R., Panetta, J., Longo, K. M., Rodrigues, L. F., Moreira, D. S., Rosário, N. E., Silva Dias, P. L., Silva Dias, M. A. F., Souza, E. P., Freitas, E. D., Longo, M., Frassoni, A., Fazenda, A. L., Santos e Silva, C. M., Pavani, C. A. B., Eiras, D., França, D. A., Massaru, D., Silva, F. B., Cavalcante, F., Pereira, G., Camponogara, G., Ferrada, G. A., Campos Velho, H. F., Menezes, I., Freire, J. L., Alonso, M. F., Gácita, M. S., Zarzur, M., Fonseca, R. M., Lima, R. S., Siqueira, R. A., Braz, R., Tomita, S., Oliveira, V., Martins, L. D., 2017. The Brazilian developments on the Regional Atmospheric Modeling System (BRAMS 5.2): an integrated environmental model tuned for tropical areas, Geoscientific Model Development, 189-222, doi: 10.5194/gmd-10-189-2017.

Gentner, D. R., Harley, R. A, Miller, A. M., Goldstein, A. H., 2009. Diurnal and seasonal variability of gasoline-related volatile organic compound emissions in Riverside, California. Environmental Science \& Technology, 43(12), 4247-52, doi: 10.1021/es9006228. 
Ginnebaugh, D. L., Jacobson, M. Z., 2012. Examining the impacts of ethanol (E85) versus gasoline production of smog in a fog using near-explicit gas- and aqueouschemistry mechanisms. Environmental Research Letters 7, 045901, doi:10.1088/1748-9326/7/4/045901.

Goel, A., Kumar, P., 2015. Characterisation of nanoparticle emissions and exposure at traffic intersections through fast-response mobile and sequential measurements. Atmospheric Environment, 107, 374-390. http://doi.org/10.1016/j.atmosenv.2015.02.002.

Gonçalves, F. L. T., Braun, S., Silva Dias, P. L., Sharovsky, R., 2007. Influences of the weather and air pollutants on cardiovascular disease in the metropolitan area of Sao $\begin{array}{llll}\text { Paulo. Environmental } & \text { Research, } & 104 & \text { (2), }\end{array}$ http://dx.doi.org/10.1016/j.envres.2007.01.004.

Gouveia, N., Fletcher, T., 2000. Times Series analysis of air pollution and mortality: effects by cause, age and socioeconomic status. Journal of Epidemiology \& Community Health, 54, 750-755, doi: 10.1136/jech.54.10.750.

Grell, G. A., Peckham, S. E., Schmitz, R., McKeen, S.A., Frost, G., Skamarock, W.C., Eder, B., 2005. Fully coupled "online" chemistry within the WRF model, Atmospheric Environment, 39, 6957-6975, doi:http://dx.doi.org/10.1016/j.atmosenv.2005.04.027.

Grimm A. M., Natori, A.A. 2006. Climate change and interannual variability of precipitation in South America. Geophysical Research Letters, 33:L19706, doi: 10.1029/2006GL026821.

Guarieiro A.L.N., Santos J.V.S., Eiguren-Fernandez A., Torres E.A., da Rocha G.O., de Andrade J.B., 2014. Redox activity and PAH content in size-classified nanoparticles emitted by a diesel engine fuelled with biodiesel and diesel blends. Fuel, 116, 490-497.

Guardani, R., Nascimento, C.A.O., Guardani, M. L. G., Martins, M. H. R. B., Romano, J., 1999. Study of Atmospheric Ozone Formation by means of a Neural Network based model. Journal of the Air \& Waste Management Association 49, 316-323, http://dx.doi.org/10.1080/10473289.1999.10463806.

Guerrero, V. V. U., 2016. Meteorological conditions associated to pollutant dispersion in São Paulo and Santiago. PhD Dissertation, Department of Atmospheric Sciences, Institute of Astronomy, Geophysics and Atmospheric Sciences, University of São Paulo, São Paulo, Brazil, 203 p, 
http://www.teses.usp.br/teses/disponiveis/14/14133/tde-20042016-161502/en.php. (accessed 04.09.2016).

Harley, R. A., Marr, L. C., Lehner, J. K., Giddings, S. N., 2005. Changes in motor vehicle emissions on diurnal to decadal time scales and effects on atmospheric composition. Environmental Science \& Technology, 39(14), 5356-62, doi: $10.1021 / \mathrm{es} 048172+$.

Hetem, I. G., Andrade, M. F., 2016. Characterization of Fine Particulate Matter Emitted from the Resuspension of Road and Pavement Dust in the Metropolitan Area of São Paulo, Brazil. Atmosphere, 7, 31-41, doi:10.3390/atmos7030031.

Hoekman, S. K., Robbins, C., 2012. Review of the effects of biodiesel on NOx emissions. Fuel Processing Technology, 96, 237-249, http://dx.doi.org/10.1016/j.fuproc.2011.12.036.

Hoffman, W. A., Schroeder, W., Jackson, R. B., 2003. Regional feedbacks among fire, climate, and tropical deforestation, J. Geophys. Res., 108(D23), 4721, doi:10.1029/2003JD003494.

Ibarra, S., Ynoue, R. Y., Mhartain, S., 2016. High resolution vehicular emissions inventory for the Metropolitan Area of São Paulo. Submitted to Atmospheric Environment in August, 2016).

IBGE, 2016. Instituto Brasileiro de Geografia e Estatística (Brazilian Institute of Geography and Statistics). http://cod.ibge.gov.br/QHF (accessed 03.02.2016).

INMET, 2016. Normais climatológicas do Brasil, 1961-1990. Available at http://www.inmet.gov.br/portal/index.php?r=clima/normaisClimatologicas. Last access: 2016, 08 August.

Jacob, D. J., 2000. Heterogeneous chemistry and tropospheric ozone. Atmospheric Environment, 34, 2131-2159, http://dx.doi.org/10.1016/S1352-2310(99)00462-8.

Jacobson, M. Z., 2007. Effects of Ethanol (E85) versus Gasoline Vehicles on Cancer and Mortality in the United States. Environmental Science \& Technology, 41 (11), 4150-4157, doi: 10.1021/es062085v.

Jacobi, P., Segura, D. B., Kjellén, M., 1999. Governmental responses to air pollution: summary of a study of the implementation of rodízio in São Paulo. Environment and Urbanization, 11(1), 79-88. http://doi.org/10.1630/095624799101284878.

Jenkins K., Nicholls, S., 2010. The impacts of climate variability and potential climate change on tourism business in Torbay, England implications for adaptation. 
Tourism

Analysis,

$15(1)$,

17-30,

doi:

http://dx.doi.org/10.3727/108354210X12724734223513.

Ji, S., Cherry, C. R., Bechle, M. J., Wu, Y., Marshall, J. D., 2012. Electric Vehicles in China: Emissions and Health Impacts. Environmental Science \& Technology, 46(4), 2018-2024, doi: 10.1021/es202347q.

Jing, P., Lu, Z., Xing, J., Streets, D.G., Tan, Q., O'Brien, T., Kamberos, J., 2014. Response of the summertime ground-level ozone trend in the Chicago area to emission controls and temperature changes, 2005-2013, Atmospheric Environment, 99, 630-640.

Karavalakis, G., Boutsika, V., Stournas, S., Bakeas, E., 2011. Biodiesel emissions profile in modern diesel vehicles. Part 2: Effect of biodiesel origin on carbonyl, $\mathrm{PAH}$, nitro-PAH and oxy-PAH emissions. The Science of the Total Environment, 409(4), 738-47. http://doi.org/10.1016/j.scitotenv.2010.11.010.

Kaufman, Y. J., Tanré, D., Boucher, O., 2002. A satellite view of aerosols in the climate system. Nature, 419, 215-223, doi:10.1038/nature01091.

Karjalainen, P., Timonen, H., Saukko, E., Kuuluvainen, H., Saarikoski, S., AakkoSaksa, P., Murtonen, T., Bloss, M., Dal Maso, M., Simonen, P., Ahlberg, E., Svenningsson, B., Brune, W. H., Hillamo, R., Keskinen, J., and Rönkkö, T., 2016. Time-resolved characterization of primary particle emissions and secondary particle formation from a modern gasoline passenger car. Atmospheric Chemistry and Physics, 16, 8559-8570, doi:10.5194/acp-16-8559-2016, 2016.

Kawashima, A.B., de Morais, M.V.B., Martins, L.D., Urbina,V., Rafee, S.A.A., Capucim, M.N., Martins, J.A., 2015. Estimates and Spatial Distribution of Emissions from Sugar Cane Bagasse Fired Thermal Power Plants in Brazil. Journal of Geoscience and Environment Protection, 3, 7276.http://dx.doi.org/10.4236/gep.2015.36012

Koren, I., Kaufman, Y. J., Remer, L. A., Martins, J. V., 2004. Measurement of the effect of Amazon smoke on inhibition of cloud formation, Science, 303, 1342- 1345, doi:10.1126/science.1089424.

Kumar, P., Robins, A., ApSimon, H., 2010. Nanoparticle emissions from biofuelled vehicles - their characteristics and impact on the number-based regulation of atmospheric particles. Atmospheric Science Letters 11, 327-331, doi: 10.1002/asl.307. 
Kumar, P., Gurjar, B.R., Nagpure, A., Harrison, R.M., 2011a. Preliminary estimates of nanoparticle number emissions from road vehicles in megacity Delhi and associated health impacts. Environmental Science \& Technology, 45, 5514-5521, doi: 10.1021/es2003183.

Kumar, P., Ketzel, M., Vardoulakis, S., Pirjola, L., Britter, R., 2011b. Dynamics and dispersion modelling of nanoparticles from road traffic in the urban atmospheric environment - a review. Journal of Aerosol Science, 42, 580-603, http://dx.doi.org/10.1016/j.jaerosci.2011.06.001.

Kumar, P., Morawska, L., Harrison, R.M., 2013a. Nanoparticles in European Cities and Associated Health Impacts. In Urban Air Quality in Europe: The Handbook of Environmental Chemistry (Editor Viana, M.). Springer Berlin Heidelberg, pp. 339365, Series Volume 26, http://dx.doi.org/10.1007/698_2012_161.

Kumar, P., Pirjola, L., Ketzel, M., Harrison, R.M., 2013b. Nanoparticle emissions from 11 non-vehicle exhaust sources - a review. Atmospheric Environment, 67, 252-277, http://dx.doi.org/10.1016/j.atmosenv.2012.11.011.

Kumar, P., Morawska, L., Birmili, W., Paasonen, P., Hu, M., Kulmala, M., Harrison, R.M., Norford, L., Britter, R., 2014. Ultrafine particles in cities. Environment International 66, 1-10, http://dx.doi.org/10.1016/j.envint.2014.01.013.

Kumar, P., Andrade, M. F., Ynoue, R. Y., Fornaro, A., Freitas, E. D., Martins, J., Martins, L. D., Albuquerque, T., Zhang, Y., Morawska, L., 2016 New directions: From biofuels to wood stoves: The modern and ancient air quality challenges in the megacity of São Paulo. Atmospheric Environment, 140, 364-369, doi: 10.1016/j.atmosenv.2016.05.059

Li, Z., Hensher, D., 2012. Congestion charging and car use: A review of stated preference and opinion studies and market monitoring evidence. Transport Policy, 20, 47-61, http://dx.doi.org/10.1016/j.tranpol.2011.12.004.

Lima, F.D.M., 2015. Quantificação e caracterização físico-química do material particulado fino (MP2,5): queima de biomassa em fornos de pizzaria na cidade de São Paulo. Master Thesis, University of São Paulo.

Lin, C.A., Martins, M.A., Farhat, S.C.L., Pope III, C.A., Conceição, G.M.S., Anastácio, V.M., Hatanaka, M., Andrade, W.C., Hamaue, W.R., Bõhm, G.M., Saldiva, P.H.N, 1999. Air Pollution and respiratory illness of children in São Paulo, Brazil. Paediatric and Perinatal Epidemiology 13, 475-488, doi: 10.1046/j.13653016.1999.00210.x. 
Lin, C.A., Pereira, L.A.A, Nishioka, D. C., Conceição, G.M.S., Braga, A.L.F., Saldiva, P.H.N., 2004. Air pollution and neonatal deaths in Sao Paulo, Brazil. Brazilian Journal of Medical and Biological Research, 37(5), 765-770, http://dx.doi.org/10.1590/S0100-879X2004000500019

Llopart M., Coppola, E., Giorgi, F. da Rocha, R. P. Cuadra, S. V., 2014. Climate change impact on precipitation for the Amazon and La Plata basins. Climatic Change, 125(1), 111-125, doi:10.1007/s10584-014-1140-1.

Longo, K. M., Freitas, S. R., Andreae, M. O., Setzer, A., Prins, E., Artaxo, P., 2010. The Coupled Aerosol and Tracer Transport model to the Brazilian developments on the Regional Atmospheric Modeling System (CATT-BRAMS) - Part 2: Model sensitivity to the biomass burning inventories, Atmospheric Chemistry and Physics, 10(13), 5785-5795, doi:10.5194/acp-10-5785-2010.

Madronich, S., 2014. Atmospheric chemistry: Ethanol and ozone. Nature Geoscience, 7(6), 395-397. http://doi.org/10.1038/ngeo2168.

Marengo J. A., Jones, R., Alves, L. M., Valverde, M. C., 2009. Future change of temperature and precipitation extremes in South America as derived from the PRECIS regional climate modeling system. International Journal of Climatology, 29, 2241-2255, doi: 10.1002/joc. 1863.

Marengo J. A., Ambrizzi, T., Rocha, R. P., Alves, L. M., Cuadra, S. V., Valverde, M. C., Ferraz, S. E. T., Torres, R. R., Santos, D. C., 2010a. Future change of climate in South America in the late XXI century: intercomparison of scenarios from three regional climate models. Climate Dynamics, 35, 1073-1097, doi:10.1007/s00382009-0721-6.

Marengo J. A., Rusticucci, M., Penalba, O., Renom, M., 2010b. An intercomparison of observed and simulated extreme rainfall and temperature events during the last half of the twentieth century. Part 2: historical trends. Climatic Change, 98, 509-529, doi:10.1007/s10584-009-9743-7.

Marengo, J. A., Aragão, L. E. O. C., Cox, P. M., Betts, R., Costa, D., Kaye, N., Smith, L. T., Alves, L. M., Reis, V., 2016. Impacts of climate extremes in Brazil: the development of a web platform for understanding long-term sustainability of ecosystems and human health in Amazonia (PULSE-Brazil). Bulletin of the American Meteorological Society, 1341-1346, doi:10.1175/BAMS-D-14-00177.1.

Marques, E. C., 2016. São Paulo in the Twenty-First Century. Spaces, Heterogeneities, Inequalities. Routledge Advances in Sociology. 246 pp. 
Marr, L. C., Harley, R. A., 2002a. Spectral analysis of weekday-weekend differences in ambient ozone, nitrogen oxide, and non-methane hydrocarbon time series in California, Atmospheric Environment, 36 (14), 2327-2335, http://dx.doi.org/10.1016/S1352-2310(02)00188-7.

Marr, L. C., Harley, R. A., 2002b. Modeling the effect of weekday-weekend differences in motor vehicle emissions on photochemical air pollution in central California. Environmental Science \& Technology, 36(19), 4099-4106. http://doi.org/10.1021/es020629x

Martin, S. T., Andreae, M. O., Althausen, D., Artaxo, P., Baars, H., Borrmann, S., Chen, Q., Farmer, D. K., Guenther, A., Gunthe, S. S., Jimenez, J. L., Karl, T., Longo, K., Manzi, A., Müller, T., Pauliquevis, T., Petters, M.D., Prenni, A.J., Pöschl, U., Rizzo, L.V., Schneider, J., Smith, J. N., Swietlicki, E., Tota, J., Wang, J., Wiedensohler, A., Zorn, S. R., 2010. An overview of the Amazonian Aerosol Characterization Experiment 2008 (AMAZE-08). Atmospheric Chemistry and Physics, 10, 11415-11438, doi:10.5194/acp-10-11415-2010.

Martin, S.T., Artaxo, P., Machado, L.A.T., Manzi, A.O., Souza, R.A.F., Schumacher, C., Wang, J., Andreae, M.O., Barbosa, H.M.J., Fan, J., Fisch, G., Goldstein, A.H., Guenther, A., Jimenez, J.L., Pöschl, U., Silva Dias, M.A., Smith, J.N., Wendisch, M., 2015. Introduction: Observations and Modeling of the Green Ocean Amazon (GoAmazon2014/5). Atmospheric Chemistry and Physics. 16, 4785-4797, doi:10.5194/acp-16-4785-2016.

Martins, L. D., Vasconcellos, P. C., Carvalho, L. R. F., Andrade, M. F., 2006. Estimated Impact of Biogenic Hydrocarbon Emissions on Photochemical Oxidant Formation in São Paulo During two Periods of the Winters of 1999-2000. Revista Brasileira de Meteorologia, 190-200, http://www.rbmet.org.br/port/revista/revista_artigo.php?id_artigo=100.

Martins, L. D., Andrade, M. F., 2008a. Emission scenarios assessment of gasohol reformulation proposals and ethanol use in the Metropolitan Area of São Paulo. The Open Atmospheric Science Journal 2, 166-175, doi: $10.2174 / 1874282300802010166$.

Martins, L. D., Andrade, M. F. 2008b. Ozone Formation Potentials of Volatile Organic Compounds and Ozone Sensitivity to their Emission in the Megacity of São Paulo, Brazil. Water, Air and Soil Pollution, 195 (1), 201-213, doi: 10.1007/s11270-0089740-x. 
Martins, L. D., Andrade, M. F., Ynoue, R. Y., Albuquerque, E. L., Tomaz, E., Vasconcellos, P.C. 2008c. Ambiental volatile organic compounds in the megacity of São Paulo. Química Nova, 31 (8), 2009-2013.

Martins, L. D., Martins, J. A., Freitas, E. D., Rocha, C. R. M., Gonçalves, F. L. T., Ynoue, R. Y., Hallak, R., Albuquerque, T. T. A., Andrade, M. F., 2010. Potential health impact of ultrafine particles under clean and polluted urban atmospheric conditions: a model-based study. Air Quality, Atmosphere and Health, 3 (1), 29-39, DOI: $10.1007 / \mathrm{s} 11869-009-0048-9$.

Martins, L. D., Silva Júnior, C. R., Solci, M. C., Pinto, J. P., Souza, D. Z., Vasconcellos, P., Guarieiro, A. L. N., Guarieiro, L. L. N., Sousa, E. T., Andrade, J. B., 2011. Particle emission from heavy-duty engine fuelled with blended diesel and biodiesel. Environmental Monitoring \&. Assessment. 184, 2663-2676, doi: 10.1007/s10661011-2142-3.

Martins, J. A., Martins, L. D., Capucim, M. N., Brand, V. S., Neves, C. P., Mazzoli, C. R., Ynoue, R. Y., Andrade, M. F., Freitas, E. D. The Application of Land Use and Nighttime Lights on the Development of High-Resolution Emission Inventories for South America. In: 4th Colombian Meeting and International Conference on Air Quality and Public Health, 2013, Bogotá. 4th Colombian Meeting and International Conference on Air Quality and Public Health. Bogotá: Universidad de La Salle, 2013. p. 619-624.

Massambani, O., Andrade, M. F., 1994. Seasonal Behavior of Tropospheric ozone in the São Paulo (Brazil) Metropolitan Area. Atmospheric Environment, 28(19), 3165-3169, doi:10.1016/1352-2310(94)00152-B.

Masson, V., 2000. A physically-based scheme for the urban energy budget in atmospheric models, Boundary-Layer Meteorology, 94(3), 357-397, doi:10.1023/A:1002463829265.

Mendez, G. F. J., Gonçalves, F L T,. Nedel, A. S., Cardoso, M. R.A., 2014. Condiciones Meteorológicas y morbidad respiratoria en niños en la ciudad de São Paulo, Brasil. Epsilon. Vol 1, No. 21.

Miranda, R. M., Andrade, M. F., Worobiec, A., Grieken, R. V., 2002. Characterisation of Aerosol Particles in the Sao Paulo Metropolitan Area. Atmospheric Environment. 36(2), 345 - 352, http://dx.doi.org/10.1016/S1352-2310(01)00363-6.

Miranda, R. M., Andrade, M. F., Fattori, A. P., 2005. Preliminary studies about the effect of aerosols on nitrogen dioxide photolysis rates in the city of São Paulo, 
Brazil. Atmospheric Research, 75 (1-2), $135 \quad-\quad$ 148, http://dx.doi.org/10.1016/j.atmosres.2004.12.004.

Miranda, R. M., Andrade, M.F., Fornaro, A., Astolfo, R., André, P.A., Saldiva, P.H., 2012. Urban air pollution: a representative survey of PM2.5 mass concentrations in six Brazilian cities. Air Quality, Atmosphere \& Health, 5(1), 63-77, doi:10.1007/s11869-010-0124-1.

Miranda, R.M., Lopes, F., Rosario, N.E., Yamasoe, M.A., Landulfo, E., Andrade, M.F. 2017. The relationship between aerosol particles chemical composition and optical properties to identify the biomass burning contribution to fine particles concentration: a case study for São Paulo city, Brazil. Environ Monit Assess. 189:6, doi: 10.1007/s10661-016-5659-7.

MME, 2014a. (BRASIL, Ministério de Minas e Energia), Resenha mensal do mercado de energia elétrica, v. 77, Empresa de Pesquisa Energética (EPE), Rio de Janeiro.

MME, 2014b. (BRASIL, Ministério de Minas e Energia), Resenha mensal do mercadode energia elétrica, v. 78, Empresa de Pesquisa Energética (EPE), Rio de Janeiro, 2014.

Monteiro dos Santos D., Brito J. F., Godoy J. M., Artaxo P., 2016. Ambient concentrations and insights on organic and elemental carbon dynamics in São Paulo, Brazil. Atmospheric Environment 144, 226-233, http://dx.doi.org/10.1016/j.atmosenv.2016.08.081.Nepstad, D. C., Lefebvre, P., Silva, U. L., Tomasella, J., Schlesinger, P., Solórzano, L., Moutinho, P., Ray, D., Benito, J. G., 2004. Amazon drought and its implications for forest flammability and tree growth: A basin-wide analysis, Global Change Biololgy, 10, 704- 717, doi:10.1111/j.1529-8817.2003.00772.x.

Niven, R.K., 2005. Ethanol in gasoline: environmental impacts and sustainability review article. Renewable and Sustainable Energy Reviews, 9(6), 535-555, http://dx.doi.org/10.1016/j.rser.2004.06.003.

Nobre, C. A., Young, A.F., Saldiva, P., Marengo, J. A., Nobre, A. D., Junior, S., Da Silva, G.C.M., Lombardo, M., 2010. Vulnerabilidade das Megacidades Brasileiras às Mudanças Climáticas: Região Metropolitana de São Paulo. Sumário Executivo, INPE, Rio Claro, SP.

Nogueira, T., Dominutti, P. A., Carvalho, L. R. F., Fornaro, A., Andrade, M. F., 2014. Formaldehyde and acetaldehyde measurements in urban atmosphere impacted by 
the use of ethanol biofuel: Metropolitan Area of Sao Paulo (MASP), 2012 and 2013. Fuel, 134, 505-513, http://dx.doi.org/10.1016/j.fuel.2014.05.091.

Nogueira, T., Cordeiro, D. S., Munoz, R. A. A., Fornaro, A., Miguel, A. H., Andrade, M. F., 2015a. Bioethanol and biodiesel as vehicular fuels in Brazil - assessment of atmospheric impacts from the long period of biofuels use. In: Biofuels - Status and Perspective. InTech, DOI: 10.5772/60944.

Nogueira, T., Souza, K. F., Fornaro, A., Andrade, M. F., Carvalho, L. R. F., 2015b. Onroad emissions of carbonyls from vehicles powered by biofuel blends in traffic tunnels in the Metropolitan Area of Sao Paulo, Brazil. Atmospheric Environment, 108, 88-97, http://dx.doi.org/10.1016/j.atmosenv.2015.02.064.

Oliveira, B. F. A., Ignotti E., Hacon S., 2011. A systematic review of the physical and chemical characteristics of pollutants from biomass burning and combustion of fossil fuels and health effects in Brazil. Cadernos de Saúde Pública, 27(9), 16781698, http://dx.doi.org/10.1590/S0102-311X2011000900003.

Oliver H., Smithers, R., Bailey, S., Walmsley, C. A., Watts, K., 2012. A decision framework for considering climate change adaptation in biodiversity conservation planning. Journal of Applied Ecology, 49, 1247-1255, http:/dx.doi.org/10.1111/1365-2664.12003.

Orsini C and Bouéres LC (1977): A PIXE system for air pollution studies in South America. Nuclear Instruments and Methods, Vol 142.

Orsini C., Artaxo P., Tabacniks M. (1984): The São Paulo PIXE system and its use on a national monitoring air quality program. Nucl. Instrum. Meth. Phys. Res. B3, pp. $462-465$.

Oyama, M. D., Nobre, C. A., 2003. A new climate-vegetation equilibrium state for tropical South America. Geophysical Research Letters, 30(23), 2199, doi:10.1029/2003GL018600.

Oyama, B. S., Andrade, M. F., Herckes, P., Dusek, U., Röckmann, T., Holzinger, R. 2015. Vehicular emissions of organic particulate matter in Sao Paulo, Brazil, Atmospheric Chemistry and Physics Discussions, 15, 33755-33788, doi:10.5194/acpd-15-33755-2015.

Parrish D., Singh, H., Molina, L., Madronich, S., 2011. Air quality progress in North American megacities: A review. Atmospheric Environment, 45, 7015-7025, http://dx.doi.org/10.1016/j.atmosenv.2011.09.039. 
Pereira, L. A. A., Loomis, D., Conceição, G. M. S., Braga, A. L. F., Arcas, R. M., Kishi, H. S., Singer, J. M., Bõhm, G. M., Saldiva, P. H. N., 1998. Association between air pollution and intrauterine Mortality in São Paulo, Brazil. Environmental Health Perspectives, 106(6), 325-329. PMC1532988.

Pereira Filho, M.A., Pereira, L.A.A., Arbex, F.F., Arbex, M., Conceição, G.M., Santos, U.P., Lopes, A.C., Saldiva, P.H.N., Braga, A.L.F., Cendon, S., 2008. Effect of air pollution on diabetes and cardiovascular diseases in São Paulo, Brazil. Brazilian Journal of Medical and Biological Research, 41(6), 526-532, http://dx.doi.org/10.1590/S0100-879X2008005000020.

Perez-Martinez, P. J., Miranda, R. M., Nogueira, T., Guardani, M. L., Fornaro, A., Ynoue, R., Andrade, M. F., 2014. Emission factors of air pollutants from vehicles measured inside road tunnels in São Paulo: Case study comparison. International Journal Environmental Science Technology, 11(8), 2155-2168, doi:10.1007/s13762-014-0562-7.

Perez-Martinez P., Andrade M. F., Miranda R. M., 2015. Traffic-related air quality trends in São Paulo, Brazil. Journal of Geophysical Research: Atmospheres 120 (12), 6290-6304, DOI: 10.1002/2014JD022812.

Pezzoli, A., Alfredini, P., Arasaki, E., Rosso, M., de Sousa Jr., W. C., 2013. Impacts of Climate Changes on Management Policy of the Harbors, Land Areas and Wetlands in the São Paulo State Coastline (Brazil), Journal of Climatology and Weather Forecasting, 1: 101. doi:10.4172/2332-2594.1000101

Pielke, R. A., Cotton, W. R., Walko, R. L., Tremback, C. J., Lyons, W. A., Grasso, L.D., Nicholls, M. E., Moran, M. D., Wesley, D. A., Lee, T. J., Copeland, J. H., 1992. A Comprehensive Meteorological Modeling System - RAMS. Meteorology and Atmospheric Physics 49, 69-91, doi:10.1007/BF01025401.

Pinheiro, S. L. L. A., Saldiva, P. H. N., Schwartz, J., Zanobetti, A. 2014. Isolated and synergistic effects of PM10 and average temperature on cardiovascular and respiratory mortality. Revista de Saúde Pública 48(6), 881-888, http://dx.doi.org/10.1590/S0034-8910.2014048005218.

Poulopoulos, S. G., Samaras, D. P., Philippopoulos, C. J., 2001. Regulated and unregulated emissions from an internal combustion engine operating on ethanol containing fuels. Atmospheric Environment, 35(26), 4399-4406, http://dx.doi.org/10.1016/S1352-2310(01)00248-5. 
Rahman, M. M., Pourkhesalian, A. M., Jahirul, M. I., Stevanovic, S., Phamb, P. X., Wang, H., Masri, A. R., Brown, R. J., Ristovski, Z. D., 2014. Particle emissions from biodiesels with different physical properties and chemical composition Fuel 134, 201-208, http://dx.doi.org/10.1016/j.fuel.2014.05.053.

Ribeiro, H., Cardoso, M. R. A., 2003. Air pollution and children's health in São Paulo (1986-1998). Social Science \& Medicine, 57(11), 2013-2022, doi:10.1016/S02779536(03)00068-6.

Rozoff, C. M., Cotton, W. R., Adegoke, J. O., 2003. Simulation of St. Louis, Missouri, Land Use Impacts on Thunderstorms, Journal of Applied Meteorology, 42(6), 716738, doi:10.1175/1520-0450(2003)042<0716:SOSLML>2.0.CO;2.

Rusticucci M., Marengo, J. A., Penalba, O., Renom, M., 2010. An intercomparison of observed and simulated extreme rainfall and temperature events during the last half of the twentieth century: Part 1: mean values and variability. Climatic Change 98:493-508, doi: 10.1007/s10584-009-9742-8.

Saldiva. P. H. N., Lichtenfels, A. J. F. C., Paiva, P. S. O., Barone, I. A., Martins, M. A., Massad, E., Pereira, J. C. R., Xavier, V. P., Singer, J. M., Bõhm, G. M., 1994. Association between Air Pollution and Mortality due to Respiratory Diseases in children in São Paulo, Brazil: A preliminary report. Environmental Research, 65(2), 218-225, doi:10.1006/enrs.1994.1033.

Saldiva, P. H. N., Pope III, C.A., Schwartz, J., Dockery, D. W., Lichtenfels, A. J., Salge, J. M., Barone, I., Bohm, G. M., 1995. Air pollution and mortality in elderly people: a time-series study in São Paulo, Brazil. Archives of Environmental Health: An International Journal, 50(2), 159-163, http://dx.doi.org/10.1080/00039896.1995.9940893.

Salvo, A., Geiger, F.M., 2014. Reduction in local ozone levels in urban Sao Paulo due to a shift from ethanol to gasoline use. Nature Geosciences, 7, 450-458, doi:10.1038/ngeo2144.

Sampaio, G., Nobre, C., Costa, M. H., Satyamurty, P., Soares-Filho, B. S., Cardoso, M., 2007. Regional climate change over eastern Amazonia caused by pasture and soybean cropland expansion, Geophysical Research Letters, 34, L17709, doi:10.1029/2007GL030612.

Sánchez-Ccoyllo, O. R., Andrade, M. F., 2002. The influence of meteorological conditions on the behavior of pollution concentration in São Paulo, Brazil. Environmental Pollution, 116 (2), 257-263, doi:10.1016/S0269-7491(01)00129-4. 
Sánchez-Ccoyllo, O. R., Ynoue, R. Y., Martins, L. D., Andrade, M. F., 2006a. Impacts of ozone precursor limitation and meteorological variables on ozone concentration in São Paulo, Brazil. Atmospheric Environment, 40(Suppl 2), 552-562. http://dx.doi.org/10.1016/j.atmosenv.2006.04.069.

Sánchez-Ccoyllo, O. R., Silva Dias, P. L., Andrade, M. F., Freitas, S. R., 2006 b. Determination Of O3-, Co- And $\mathrm{Pm}_{10}$-transport in the metropolitan area of São Paulo, Brazil through synoptic-scale analysis of back trajectories. Meteorology and Atmospheric Physics, 92(1), 83-93, doi: 10.1007/s00703-005-0139-6.

Sánchez-Ccoyllo, O. R., Martins, L. D., Ynoue, R. Y., Andrade, M. F., 2007. The impact on tropospheric ozone formation on the implementation of a program for mobile emissions control: a case study in São Paulo, Brazil. Environmental Fluid Mechanics, 7 (2), 95-119, doi: 10.1007/s10652-007-9018-7.

Sánchez-Ccoyllo OR, Ynoue RY, Martins LD, Astolfo R, Miranda RM, Freitas ED, Borges AS, Fornaro A, Freitas H, Moreira A, Andrade MF, 2009. Vehicular particulate matter emissions in road tunnels in Sao Paulo, Brazil. Environ Monit Assess 149(1-4):241-249.

Santos, G., 2005. Urban congestion charging: a comparison between London and Singapore. Transport $\quad$ Reviews, 25(5), 511-534, http://dx.doi.org/10.1080/01441640500064439.

Segalin, B., Kumar, P., Micadei, K., Fornaro, A. and Gonçalves, F.L.T., 2016. Sizesegregated particulate matter inside residences of elderly in the Metropolitan Area of São Paulo, Brazil. Atmospheric Environment, 148, 139-151. doi.org/10.1016/j.atmosenv.2016.10.004

Sharovsky, R., L. A. M. César, and J. A. F. Ramires., 2004. Temperature, air pollution, and mortality from myocardial infarction in São Paulo, Brazil. Brazilian journal of medical and biological research, 37 (11), 1651-1657, http://dx.doi.org/10.1590/S0100-879X2004001100009.

Silva, C. B. P., Saldiva, P. H. N., Amato-Lourenço, L. F., Rodrigues-Silva, F., Miraglia, S. G. E. K., 2012. Evaluation of the air quality benefits of the subway system in São Paulo, Brazil. Journal of Environmental Management, 101, 191-196. http://doi.org/10.1016/j.jenvman.2012.02.009.

Silva Dias, M. A. F., Dias, J., Carvalho, L. M. V., Freitas, E. D., Silva Dias, P. L., 2013, Changes in extreme daily rainfall for São Paulo, Brazil, Climatic Change, 116(3-4), 705-722, doi:10.1007/s10584-012-0504-7. 
Son, J., Gouveia, N., Bravo, M. A., Freitas, C. U., Bell, M. L., 2016. The impact of temperature on mortality in a subtropical city: effects of cold, heat, and heat waves in São Paulo, Brazil. International Journal of Biometeorology, 60(1), 113-121. http://doi.org/10.1007/s00484-015-1009-7.

Souto-Oliveira C., Kumar, P., Lopes, F., Landulfo, E., Babinski, M., Andrade, M. F. 2016. Effect of local and remote sources and new particle formation events on the activation properties of cloud condensation nuclei in the Brazilian megacity of São Paulo. Atmosphere Chemistry and Physics Discussion, submitted.

Souza, D. Z., Vasconcellos, P. C., Lee, H., Aurela, M., Saarnio, K., Teinilä, K., Hillamo, R., 2014. Composition of PM2.5 and PM10 collected at urban sites in Brazil. Aerosol and Air Quality Research, 14, 168-176, doi: 10.4209/aaqr.2013.03.0071.

Stedman, D. H., 2004. Photochemical ozone formation, simplified, Environmental Chemistry, 1, 65-66, doi: 10.1071/EN04032.

Suarez-Bertoa R., Zardini, A. A., Platt, S. M., Hellebust, S., Pieber, S. M., Haddad, I., Temime-Roussel, B., Baltensperger, U., Marchand, N., Prevot, A. S. H., Astorga, C., 2015. Primary emissions and secondary organic aerosol formation from the exhaust of a flex-fuel (ethanol) vehicle. Atmospheric Environment, 117, 200-211, http://dx.doi.org/10.1016/j.atmosenv.2015.07.006.

Surendran D. E., Ghude, S. D., Beig, G., Emmons, L.K., Jena, C., Kumar, R., Pfister, G. G., Chate, D. M., 2015. Air quality simulation over South Asia using Hemispheric Transport of Air Pollution version-2 (HTAP-v2) emission inventory and Model for Ozone and Related Chemical Tracers (MOZART-4). Atmospheric Environment, 122, 357-372, http://dx.doi.org/10.1016/j.atmosenv.2015.08.023.

Thunis, P., Miranda, A., Baldasano, J. M., Blond, N., Douros, J., Graff, A., Janssen, S., Juda-Rezler, K., Karvosenoja, N., Maffeis, G., Martilli, A., Rasoloharimahefa, M,, Real, E., Viaene, P., Volta, M., White, L., 2016. Overview of current regional and local scale air quality modelling practices: Assessment and planning tools in the EU. Environmental Science \& Policy, 65, 13-21, http://dx.doi.org/10.1016/j.envsci.2016.03.013.

Ulke, A. G., Andrade, M. F., 2001. Modeling urban air pollution in São Paulo, Brazil: sensitivity of model predicted concentrations to different turbulence parameterizations. Atmospheric Environment, 35 (10), 1747-1763, http://dx.doi.org/10.1016/S1352-2310(00)00498-2. 
UN, 2014. United Nations, Department of Economic and Social Affairs, Population Division (2014). http://esa.un.org/unpd/wup/highlights/wup2014-highlights.pdf (accessed 04.02.2016).

Vara-Vela, A, Andrade, M. F., Kumar, P., Ynoue, R. Y., Muñoz, A. G., 2016. Impact of vehicular emissions on the formation of fine particles in the Sao Paulo Metropolitan Area: a numerical study with the WRF-Chem model. Atmospheric Chemistry and Physics, 16, 777-797, doi:10.5194/acp-16-777-2016.

Vasconcellos, P. C., Souza, D. Z., Sánchez-Ccoyllo, O., Bustillos, J. O. V., Lee, H., Santos, F. C., Nascimento, K. H., Araújo, M. P., Saarnio, K., Teinilä, K., Hillamo, R., 2010. Determination of anthropogenic and biogenic compounds on atmospheric aerosol collected in urban, biomass burning and forest areas in São Paulo, Brazil. Science of the Total Environment, 408(23), 5836-5844, http://dx.doi.org/10.1016/j.scitotenv.2010.08.012.

Vendrasco, E. P., Dias, P. L. S., Freitas, E. D., 2009. A case study of the direct radiative effect of biomass burning aerosols on precipitation in the Eastern Amazon, Atmospheric Research, 94(3), 409-421, doi:10.1016/j.atmosres.2009.06.016.

Vera, C., Silvestri, G., Liebmann, B., González, P., 2006. Climate change scenarios for seasonal precipitation in South America from IPCC-AR4 models, Geophysical Research Letters, 33:L13707, doi: 10.1029/2006GL025759.

Vivanco, M. G., Andrade, M. F., 2006. Validation of the emission inventory in the Sao Paulo Metropolitan Area of Brazil, based on ambient concentrations ratios of $\mathrm{CO}$, NMOG and NOx and on a photochemical model. Atmospheric Environment, 40(7), 1189-1198, doi:10.1016/j.atmosenv.2005.10.041.

Waked, A., Afif, C., Seigneur, C., 2015. Assessment of source contributions to air pollution in Beirut, Lebanon: a comparison of source-based and tracer-based modeling approaches. Air Quality, Atmosphere \& Health (2015) 8 (5), 495-505, doi:10.1007/s11869-014-0298-z.

Wang, S., Hao, J., 2012. Air quality management in China: Issues, challenges, and options. Journal of Environmental Sciences, 24 (1), 2-13, doi:10.1016/S10010742(11)60724-9.

Wu, L., H. Su, Jiang, J. H., 2011. Regional simulations of deep convection and biomass burning over South America: 1. Model evaluations using multiple satellite data sets, Journal of Geophysical Research, 116, D17208, doi:10.1029/2011JD016105. 
Ynoue, R. Y., Andrade, M. F., 2004. Size Resolved Mass Balance of Aerosol Particles over São Paulo Metropolitan Area, Brazil. Journal of Aerosol Science Technology, 38, 52 - 62, http://dx.doi.org/10.1080/02786820490466756

Young A. F., 2013. Urban expansion and environmental risk in the Sao Paulo Metropolitan Area. Climate Research, 57(1), 73-80, doi:10.3354/cr01161.

Younga L., Liou Y., Cheng M., Lu J., Yang H., Tsai Y.I., Wang L., Chen C., La J., 2012. Effects of biodiesel, engine load and diesel particulate filter on nonvolatile particle number size distributions in heavy-duty diesel engine exhaust. J Hazard Mater; 199-200, 282-289. 